\title{
What Is Public Agency Strategic Analysis (PASA) and How Does It Differ from Public Policy Analysis and Firm Strategy Analysis?
}

\author{
Aidan R. Vining \\ Beedie School of Business, Simon Fraser University, 500 Granville Street, Vancouver, BC V6C 1W6, Canada; \\ vining@sfu.ca; Tel.: +1-778-782-5249
}

Academic Editor: Jonathan G. Boston

Received: 1 October 2016; Accepted: 24 November 2016; Published: 8 December 2016

\begin{abstract}
Public agency strategic analysis (PASA) is different from public policy analysis because public agency executives face numerous constraints that those performing "unconstrained" policy analysis do not. It is also different from private sector strategic analysis. But because of similar constraints and realities, some generic and private sector strategic analysis techniques can be useful to those carrying out PASA, if appropriately modified. Analysis of the external agency environment (external forces) and internal value creation processes ("value chains", "modular assembly" processes or "multi-sided intermediation platforms") are the most important components of PASA. Also, agency executives must focus on feasible alternatives. In sum, PASA must be practical. But public executives need to take seriously public value, and specifically social efficiency, when engaging in PASA. Unless they do so, their strategic analyses will not have normative legitimacy because enhancing public value is not the same as in some versions of public value or in agency "profit maximization". Although similarly constrained, normatively appropriate public agency strategic analysis is not "giving clients what they want" or "making the public sector business case". PASA must be both practical and principled.
\end{abstract}

Keywords: public agency; strategic analysis; external environment; resources; value creation; social efficiency; public value; value chain; modular assembly; multi-sided platform

\section{Introduction}

Public agency strategic analysis (PASA) is different from public policy analysis, whether based on cost-benefit analysis, cost-effectiveness analysis or some form of multi-goal analysis. Public agency executives face analytic, resource and political constraints in performing program strategic analysis that those performing "unconstrained" policy analysis, such as central agency analysts, academics or think tank analysts, do not face. Private sector executives and strategists do face similar kinds of constraints as public agency executives, so their analytic techniques can be useful to those performing PASA, if appropriately modified. Joint analysis of the external agency environment (external forces) and an agency's internal value creation processes (whether "value chains", "modular assembly" processes or "intermediation platform" processes) are the most important components of PASA and business unit strategic analysis. Agency executives can learn from private sector strategic analysts use of tools that structure analysis of external environments and internal value creation. Also because of the reality of constraints, agency executives must focus on feasible alternative strategies. To be impactful, like good firm strategic analysis, PASA must be practical. Of course, public executives are well aware of this, but they do not always have the toolkit to implement practical strategic analysis.

But, practicality is not enough. Public executives and public strategic analysts must also take public value, and social efficiency specifically, seriously. Unless they do so when performing PASA, 
it will not have fundamental normative legitimacy. There is increasing recognition of the centrality of "public value" to meaningful PASA at some abstract level. More contentiously, however, I argue that some versions of public value are inimical to the social efficiency version of public value, while other versions are essentially uncorrelated with it. So PASA should not mimic private sector "profit maximization" from a goal perspective (espoused by some governments as appropriate public value), even though it can use some of the same tools as private sector strategy. Agency "profit" or revenue enhancement is not equivalent to improving social efficiency. Although constrained, normatively appropriate PASA is neither "giving clients what they want" nor "making the business case" (even though the exhortation to agencies to "make the business case" is often so methodologically vague that it simply confuses rather than directs or constrains agencies).

The rest of the paper is organized as follows. Section 2 explains why PASA can be valuable, provided the analysis meets certain conditions. Section 3 explains why PASA is different from both policy analysis and private sector strategic analysis. Section 4 expands on the difference by reviewing the many meanings of public value and the appropriate purpose of PASA. It makes the case that PASA must be at least somewhat grounded in a social efficiency version of public value to be principled. The "somewhat" provides quite a bit, but not total, room for practicality and the recognition of constraints. Sections 5-7 lay the PASA framework out in detail: Section 5 focuses on external analysis; Section 6 focuses on internal agency analysis and Section 7 on feasible alternatives and the role that agency (and more specifically program) autonomy plays in determining autonomy. The final section presents some conclusions.

\section{Why Should Agencies Perform Public Agency Strategic Analysis (PASA)?}

Why should agency executives perform PASA? (Or to put the question more colloquially: Que PASA?) One major reason is that the strategies of public organizations help determine their performance [1-4]. Good strategies depend, at least partially, on the ability of agency executives and analysts to consider, develop and implement them: that is on their practice of strategic analysis $[5,6]$. Meaningful strategic analysis for any organization, however, is costly, if only in terms of the opportunity cost of time. Furthermore, analysis requires tangible and intangible resources and skills (including requisite knowledge and cognitive willingness to forego "the quiet life") and the appropriate tools to perform it [6]. Some of these elements for performing strategic analysis can be acquired externally (for example, by using consultants), but others must be available internally, at least in the short-run, to be effective [7]. Given the substantial costs of analysis, many public organizations do not perform formal analysis. Unless strategies that embody explicit analysis are externally imposed, the strategies of these agencies are necessarily the result of implicit and informal strategizing or of pure organizational drift.

When explicit analysis is undertaken, it may be primarily backward looking and evaluative: whether in the form of a "report card" [8], a multi-goal evaluation [9] (pp. 340-382) or a "balanced scorecard" [10,11]. Even when external actors produce a performance assessment comparing the performance of different agencies delivering the same service, it usually does not directly address future performance or the potential for better strategies. Of course, service users, funders or legislatures may subsequently demand action based on an unsatisfactory assessment or ranking. But a report card or scorecard is not intrinsically a strategic document. It only becomes so if either internal or external actors successfully induce strategic analysis and subsequent strategic change.

A forward-looking exercise combines analysis that assesses current performance with analysis that raises (however informally) questions about how things should be done differently in the future. However, a great deal of valuable organizational change analysis is not oriented to the potential for strategic change even though it might lead to it, because "culture eats strategy" [12-14]. Both private sector and generic management tools are useful for this purpose, but they do not draw on strategy concepts and are not the focus here, even if the proposed "change" would be radical [15-18].

Strategic analysis may be initiated because some relevant political or executive authority believes that the agency should fundamentally re-evaluate the relevance and validity of the goals or strategies 
that underlie and justify the existence of the program, unit or agency. This call inevitably presages an exercise that can challenge the rationale for the existence of the agency or at least the rationale for a program within it. This form of analysis is both prospective and existential! It is the rationale and mandate for some form of public agency strategic analysis.

How should public agencies actually go about doing such strategic analysis? There are a number of potential meta-strategies. One response is to muddle along, or more formally, to rely primarily on "incrementalism", whether conceived as either logical or disjointed $[19,20]$. Another meta-strategy response is to focus on using and learning from simple strategy heuristics, especially in the presence of unpredictable and changing environments [21,22]. For public agencies, these heuristics would primarily result in considering mimetic strategies [23,24]. Another meta-strategy is to engage in an explicit exercise based on "relevant" theory, heuristics, experience and mimetic learning: the focus here. Which theories are relevant? This paper makes the case that some theories and tools derived from private-sector strategic analysis and management, when appropriately modified, can be useful. But, their use should be based on a clear understanding of the difference both between PASA and "classic" policy analysis and between PASA and private sector strategic analysis.

\section{How Is PASA Different from Public Policy Analysis and from Private Sector Strategic Analysis?}

\subsection{PASA Compared to Policy Analysis ...}

There are various meanings and versions of public policy analysis [9,25]. Scholars differ widely on the appropriate breadth of policy analysis. Unsurprisingly, many of these differences arise because analysts within an agency, external analysts in central government agencies and analysts outside government (academics, consultants and think tankers) have different purposes, interests and tightness of constraints. Consequently, their analyses vary importantly in the breadth of their goals and the comprehensiveness of their analyses [25]. Partly because of the difference in constraints, public agency strategic analysis is different from all standard versions of policy analysis. As argued below, this is the case even when the strategic analysis embraces a normatively appropriate version of "public value". The "normatively appropriate" caveat is crucial because not all meanings of public value are defensible on normative grounds; these meanings are less valuable as guides to any evaluation of policy alternatives. In a "worst case" analysis, policies based on an inappropriate version of public value could reduce social efficiency. I argue that unless social efficiency is a significant component of the meaning of public value, public agency strategic analysis cannot be normatively justified. To some, this is uncontroversial, indeed, it is obvious and social efficiency is included in a number of versions of public policy analysis (whether it is either explicitly argued or implicitly embedded). But, PASA is different from policy analysis because it is strategic and it is quite constrained; most policy analysis is not.

PASA is to some extent, as Bryson, et al. [26] (p. 713) put it, about providing the agency with "a valid livelihood scheme". Bryson and his colleagues further argue that the livelihood needs to be at least partly based on exploiting the agency's existing or exploitable agency "distinctive competencies". Almost by definition, analyzing a viable livelihood scheme is a strategic exercise that requires analytic capacity $[27,28]$. A practical orientation, not surprisingly, resonates with public executives and some public management scholars [29]. Agency executives with the requisite analytic capacity understand, can capitalize on, and (over time) enhance their capabilities and resources: that is, perform internal analysis that facilitates strategic change. They also understand the nature and constraints of the external environment and the threats and opportunities emanating from it: that is, the reality of their external environment. Many of these external threats are completely exogenous: that is, their parameters cannot be altered by agency strategic actions, at least in the short-run. Strategic analysis and action must, therefore, take these aspects of the external environment as given. But in some circumstances, aspects of the external environment are endogenous: agency strategic actions can alter them; this part of the environment is strategic. Based on a combined analysis of the internal and the external, an agency livelihood scheme focuses on realizable changes to current strategy. This focus on 
feasible strategy establishes a degree of equivalence to private sector strategic analysis and opens up the use of some private sector analytic tools by public executives. But, unless a livelihood is grounded in some defensible notion of public value, strategic practicality can amount to nothing more than better rent extraction by an agency for the benefit of executives, employees, elected politicians, oligarchies or dictators, or indeed anyone else that can get in on the game [30,31]. This is certainly a strategic game, but it is not normatively justifiable or valuable.

The differences between public agency strategic analysis and policy analysis are important and mean that PASA is not a substitute for a fully formed policy analysis or comprehensive social cost-benefit analysis [32]. What are some of the most important differences?

The first difference is that PASA often has a narrower jurisdictional standing focus and is necessarily interested in, and constrained by, the costs and benefits of the specific jurisdiction and its residents. In many cases its "standing" perspective is more limited than that used, and usually judged to be appropriate, for policy analysis or cost-benefit analysis (CBA) purposes [32,33]. To be normatively valuable in the narrower jurisdictional boundary situation, however, a PASA should ideally include all real (as against pecuniary) within-jurisdiction impacts and so be more than a pure agency or even government revenue-expenditure analysis [34-36]. Even if the analysis cannot measure all within-jurisdiction impacts, it should clarify which it cannot measure. A Riverside County Department of Social Services analysis, for example, would legitimately (and practically) focus on only those impacts that accrue to the residents of the county. In contrast, the standard CBA argument is that the boundaries of public policy analysis, and consequently "standing", should be governed by constitutional boundaries $[33,37,38]$. Although there is literature on global standing and other standing inclusion issues, there is little guidance on issues relating to "regional" or "local" standing [33]. In practice, this means that governments of lower sub-state entities, such as counties, are unlikely to ever perform social efficiency analysis involving any systematic social accounting of costs and benefits as understood in CBA. This does not mean that the concept of social efficiency becomes meaningless at a sub-state or sub-provincial level provided these analyses go beyond an agency revenue-expenditure ("fiscal impacts" analysis). But it does mean that PASA is almost never equivalent to a national or state level policy analysis focusing on social efficiency [39].

Second, many PASAs encompass social values beyond efficiency, especially equity. Of course, some policy analysis also has this dual goal focus. Ideally, the selected measure of social efficiency in a PASA is reasonably comprehensive, although there are always trade-offs between comprehensiveness and comprehensibility [40]. In sum, a PASA is usually both narrower in some ways and broader in others than is a "pure" social CBA.

Third, for strategic purposes, a PASA should include both an analysis of the agency/program's economic and political environment (external analysis) and an assessment of its own assets and social value creation process (internal analysis) [39]. External analyses must often be performed separately on each of an agency's programs because environments vary from program-to-program (for example, one program environment may foster natural monopoly, while that of another program may be highly competitive. Many policy analyses do not address program-level environment issues at all, because they are less relevant when adopting a state or national standing (where many of these impacts are pecuniary transfers which offset each other). Almost none address the standing complexities that are introduced by intergovernmental transfers that obscure the appropriate level of standing, even though they are pervasive in federal systems. (CBA theory is also largely silent on the topic of intergovernmental transfers and its potential impact on appropriate standing.) Although there are useful policy analysis tools, the tools of firm strategic analysis and applied industrial organization are actually more useful, especially for assessing external economic factors. The purpose of internal analysis is to initially categorize and inventory the agency's bundle of intangible assets (attributes) and tangible assets and then, more importantly, to describe and assess the processes by which the use of these assets create, or not, some version of social value or efficiency [41]. 
Combined external and internal analysis set the stage for an overall assessment of the value of strategic change because they combine (using evolutionary biology terminology) phylogenetic analysis (of an environment) with ontogenetic analysis (of an organism, or the internal) [42]. This provides a detailed description of program or agency behavior and performance, as explained below (cf., [43]). This combination also provides a framework for an evaluation of agency autonomy (the tightness of constraints) and the range of feasible alternatives. Agency autonomy, and therefore feasible alternatives, varies widely across agencies and programs.

A fourth difference is that a PASA focuses on the specific feasible agency alternatives. Most policy analysis, especially that performed by academic policy analysts, sets itself the legitimate (and luxurious) task of imagining, formulating and evaluating optimal policy alternatives. PASA analysts enjoy no such freedom. All agencies face both financial and policy constraints [44]. Agency strategic degrees of freedom are constrained by fiscal constraints on both spending and on the imposition of costs on other government agencies (that may be suppliers or purchasers) or on third parties. Many agencies also face major policy constraints imposed by external government actors: whether executive, regulatory or legislative. The combined policy and fiscal degrees of freedom shape the level and type of agency autonomy: some agencies have policy freedom, but are highly constrained fiscally, while others face the opposite reality [44].

\subsection{PASA Compared to Firm Strategic Analysis}

Strategy is important for public agencies [45-47]. The rationale for a strategic orientation is that "in the public sector, the clarity of a financial bottom line does not exist but it is equally essential that everyone in the organization has a clear understanding of strategy, and their role in achieving it" [48] (p. 637). PASA is fundamentally different from firm or business unit strategic analysis because of the goal difference. Even beyond this difference, however, public agencies can only use some of the same components and tools, and only when they are modified to account for the structural differences in environments between the public and private sectors. Given the differences, the usefulness of firm strategic analysis flows mostly from the fact that it is intrinsically strategic, whereas policy analysis is not.

Figure 1 summarizes both the public agency strategic analysis framework and some of the major issues associated with these major framework components. The laying out and discussion of the framework components provides the basic structure for the rest of this paper. The major components are: (1) the centrality of social efficiency to normatively appropriate PASA; (2) systematic consideration of the economic and political environment that an agency or even program encounters; (3) assessment of the internal resources of the agency and the potential for enhanced (social) value creation; and (4) assessment of feasible alternatives.

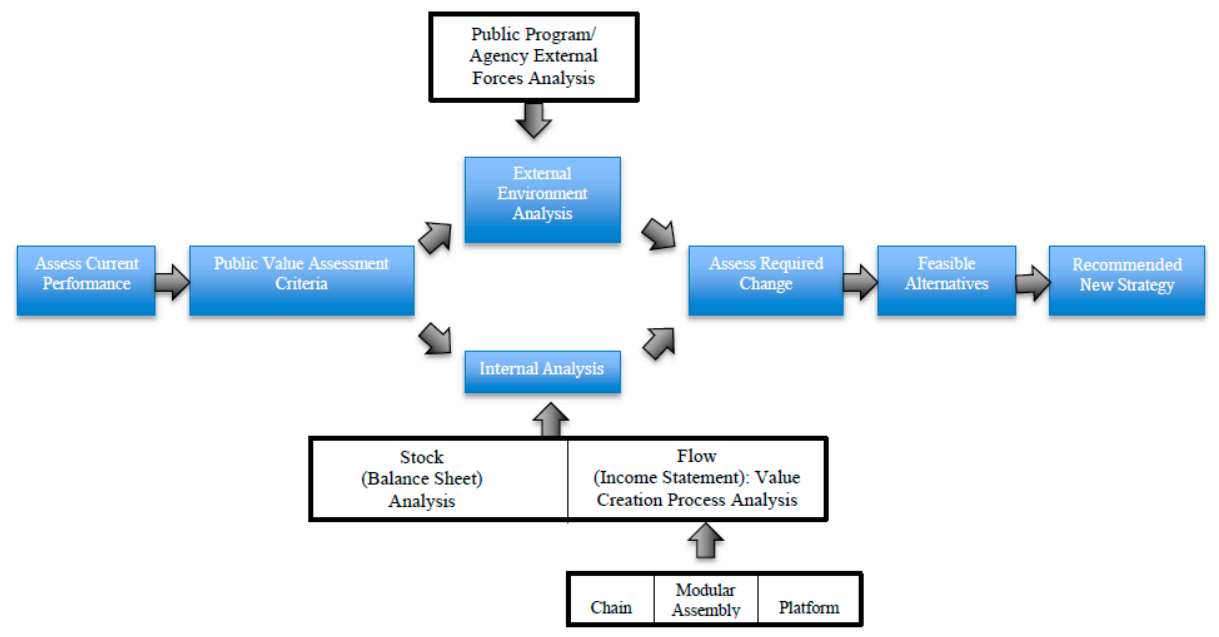

Figure 1. Public Agency Strategic Analysis Framework. 


\section{Goals: The Importance of Social Efficiency to the Meaning of Public Value}

\subsection{The Many Meanings of Public Value}

There is certainly consensus that agencies should act purposively for social good [49], but there is less agreement on its operational meaning. A number of influential scholars [50-55] have argued that public executives should focus on creating "public value". Public management scholars in a number of countries have addressed the relevance of the public value concept [56-62]. Over the last decade, senior government executives and consultant practitioners have also shown increased interest in public value [63-68].

Moore [69] presented four distinct meanings of public value: (1) the achievement of political mandates; (2) the achievement of professional standards; (3) the application of analytic techniques, such as revenue-cost analysis, cost-effectiveness analysis, or cost-benefit analysis (essentially the social efficiency perspective, although the focus is on the technique rather than the maximization of social efficiency), and (4) stakeholder and customer satisfaction. An obvious concern is that these four meanings are, in practice, quite different from each other. Additionally, the first and fourth meanings of public value are quite different from a social efficiency meaning of public value (see below). Indeed, pursuing either the first or fourth versions would conflict with achieving enhanced social efficiency [44]. Other meanings of public value proposed by other scholars or practitioners are also inconsistent with a social efficiency meaning of public value. Based on survey evidence from public executives, Andersen et al. [70] found seven dimensions of value: "the public at large", rule abidance, balancing interests, budget keeping, efficient supply, professionalism and user focus. These values are problematic from a normative perspective for several reasons. First, many of these dimensions are at different levels of analysis and not directly comparable to each other in any meaningful way (for example, "budget keeping" and "professionalism"). Second, several do not appear to have normative grounding from a substantive policy perspective, if one did manage to combine them in some multi-goal analysis or "optimizing" perspective. Among the seven, only efficient supply and user focus overlap significantly with social efficiency as defined here.

\subsection{The Meaning of Social Efficiency and Some Things It Is Not}

As will be clear by now, the argument here is that an irreducible goal of a public agency should be on increasing social efficiency or social value (used interchangeably) where it can reasonably be treated as the only policy goal [71-74]. The use of "increasing" rather than "maximizing" is one way of recognizing the many constraints that agencies face. Where there are legitimate social values in addition to social efficiency, social efficiency should have at least some weight and be included in the multi-goal analysis [75] (pp. 348-363). Some agencies engage in strategies that do appear to closely reflect social efficiency or even some more general notion of social welfare improvement [68]. Many other agencies, however, appear to be more concerned with either maximizing stakeholder satisfaction, maximizing the agency's political support, increasing the agency budget, increasing the agency's sources of non-government revenue or maximizing their discretionary budget [34]. In some cases, agencies are actually happy to publicize their commitment to one of these goals [44]. It is possible, of course, that in some circumstances that one of these goals could be positively correlated with social value, but they are more likely to be negatively correlated [76].

The general case for the primacy of the goal of social efficiency has been clearly made [71-74]. However, the meaning and application of social efficiency in particular policy and strategic contexts requires elaboration. The distinctions between technical efficiency, allocative efficiency and dynamic efficiency are important and the practical proxies that can be used for each in either PASA or policy analysis vary. Additionally, to be useful for PASA purposes, one must demonstrate that social efficiency is a practical criterion that public agency executives can measure and use to operationalize the pursuit of public value $[29,77]$. 
I consider some of implications of the use of social efficiency in the context of both the external forces and internal resource assessment that confront agencies. This can be illustrated most clearly by contrasting the outcomes associated with a social efficiency perspective on public value to outcomes associated with the stakeholder interest maximization perspective on it [78]. A long tradition in welfare economics argues that social efficiency is the most appropriate normative goal for public sector entities [71-74]. This does not preclude the inclusion of other goals, such as equity, from consideration as discussed below. However, economists have not spelled out what social efficiency (or social welfare, or public value) means in terms of policy analysis practice (little has been written about PASA at all until the last ten years). This problem is compounded by the use of differing terminology to describe the how social efficiency should be measured in practice. Some public management scholars analogize directly to private sector practice and propose the use of public return on investment or ROI [79,80] or economic rate of return (ERR) terminology [81].

Whatever the specific language, an assessment of social efficiency requires the agency to perform or access some form of analysis that assesses both costs and benefits that accrue to all those with standing, using some reasonable time frame for the program's impact: that is, it should be based on the net present value (NPV), rather than just the current period. Given PASA's practical orientation, an analysis would normally not give standing to the residents' of funding agencies even though that might be appropriate for standard CBA or policy analysis. There is some confusion or disagreement over what CBA actually is [34,82]. Sometimes it is not possible for an agency to conduct a comprehensive assessment of both social costs and benefits and the analysis can only examine changes in costs or use other related methods [36]. The crucial claim is that to have normative legitimacy, the analysis cannot not limit itself to any impact on incremental revenues (expenditures) that accrue to the agency or even to its impact on overall government expenditures and revenues (revenue-expenditure analysis), but should include all real external (to government) costs and benefits accruing to those with jurisdictional standing.

In sum, social efficiency can be quite different from many other meanings of public value. To illustrate this, Figure 2 summarizes a comparison of the social efficiency perspective and the stakeholder perspective. Simplifying somewhat, it clarifies that social efficiency attempts to focus on costs or benefits accruing to all members of the jurisdiction, while stakeholder analysis focuses on groups that can articulate the impacts on them in some organized way. The comparison highlights how the specific formulation of public value is likely to structure the whole analysis, especially the selection of the set of alternatives and the preferred strategy [44].

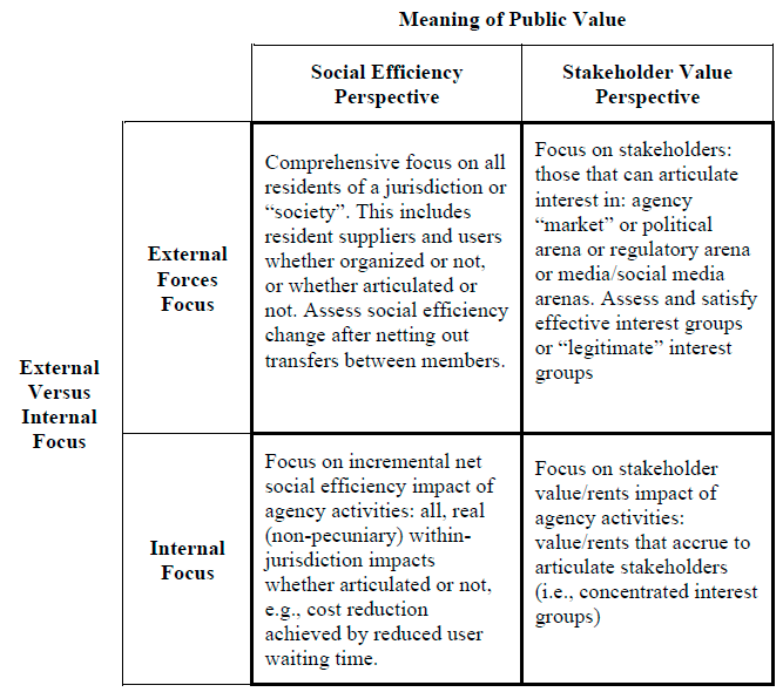

Figure 2. The Difference Between, and Consequences of, Two Distinct Meanings of Public Value: Social Efficiency Perspective versus Stakeholder Perspective. 
The importance of the specific public value formulation can be more concretely illustrated by examining how a public transportation agency might analyze road or bridge pricing under three different versions of public value: social efficiency, government revenue maximization and stakeholder analysis. Pricing based on social efficiency would focus on social marginal cost (considering primarily both congestion costs and environmental externality costs). This goal focus would point to a strategy that includes a time-of-day pricing scheme, where differing levels of congestion drive the differential pricing (and with a zero price when the road is uncongested). In contrast, a revenue maximization goal would probably focus on the demand elasticity of various user segments; these elaticities would not normally correspond with the social marginal cost pricing imposed by the user segment. This strategy would result in positive tolls based on which user segments have inelastic demand; congestion and social marginal cost would be irrelevant! Stakeholder analysis might also focus on segment demand elasticities, but in this case based on a given user segment's (that is, interest group's) ability to effectively influence the agency either directly or indirectly through political influencers [83]. Truckers, a well-organized interest group, might be able to secure volume discounts. This example thus illustrates the reality that social efficiency may be best for everyone, but often has little organized support or even within the agency [84].

\section{External (Environmental) Analysis}

Systematic consideration of the external economic and political environment is a key component of strategic analysis and is especially relevant to public agency executives because they face complex external environments $[44,85]$. Lack of fit of the current strategy with the external environment is one important reason for strategic failure among public agencies $[2,46,86]$. The empirical evidence does suggest that a strategic orientation can help improve performance on a number of dimensions $[87,88]$.

The component of the framework used here to analyze the external environment derives from the industrial organization perspective underlying the "five competitive forces" framework that is used extensively in firm (specifically, business unit) external environmental analysis [89,90]. But, because public agency environments are often characterized by a lack of competition and consequently a greater importance of other factors, it is more accurate to describe the relevant forces as "external forces" rather than as "competitive forces" - although some public programs do face competitors, potential competitors or contestability where the term competitive forces would be directly applicable. Although the competitive forces framework provides useful analytic insights for public agencies, it requires a number of significant modifications for public agency use [44]. These modifications ultimately flow from the differing goals of the private and public sectors: that is, on the difference between profit maximization and social efficiency (and social value more generally) [51,69]. But other needed modifications are driven by structural differences between the environments of private sector industries and (most) public agencies. The starkest modification based on the difference in the environments is that it makes sense to explicitly recognize political influence as an important external force in PASA. Inclusion of the political influence force requires a consideration of the factors that determine the variability of barriers to political influence across public agencies and programs.

Given that significant modifications are required, why retain the basic structure and flavor of the competitive forces model? The advantage of the model, especially compared to the most popular alternative, SWOT, is that the extent of bargaining leverage and thus overall threat assessment are grounded in industrial organization and ultimately applied microeconomics [91]. In contrast, the external component of SWOT, namely opportunities $(\mathrm{O})$ and threats $(\mathrm{T})$ is not; moreover, it is difficult to incorporate into a more comprehensive strategic analysis [91,92]. Despite its weaknesses, public agencies use SWOT more extensively than any other external analysis tool [93,94].

Figure 3 summarizes the public agency external forces framework and summarizes many generic determinants relating to these forces [44]. The public agency five forces are (in the order discussed below): supplier bargaining power, threat of substitutes/entry barriers, user/purchaser bargaining power, extent of rivalry (actual competition or the threat of contestability) and political influence 
barriers. As explained below, this differs from the competitive forces model in that political influence barriers are introduced as a separate force, while "entry barriers" and "the threat of substitutes" are combined into a single force. However, the first three forces are similar to those faced by firms in markets. It is worth reiterating that "forces" analysis needs to be conducted at the program rather than the agency level, even if only one force differs at the program level. The competitive forces framework diagrammatically shows all forces as flowing from external forces to (implicitly) the public organization being analyzed. This can be a considerable oversimplification in the public sector. In the public agency context, though, it is still useful to think of the agency or program as located as the central box and as all five forces (including competition where relevant) as impinging on it. However, where the agency is in a monopoly position (including plausible contestability, because there would still only be a single agency), the agency usually has considerable reciprocal bargaining power versus external forces and thus an ability to respond strategically to all threats and influences. Even in the absence of monopoly, the agency often has some capacity to negotiate and the legitimacy to propose (threaten!) some strategic response to some forces. Figure 3, therefore, shows bargaining power as both flowing "in" from external sources (solid lines) and (usually more weakly) flowing "out" (dotted lines) from the agency (identifying actual agency program bargaining power and influence requires specific strategic analysis).

The threat of entry and substitutes, however, are not shown as a bidirectional force because it is very unlikely that a public agency has any real power or influence over this force: the emergence of a substitute technology or new organizational forms will generally be completely exogenous to any potential strategic behavior by the agency. Political influence is shown as a bidirectional force because some agencies can take strategic action that affects the extent of political influence. This is because there is usually more than one potential source of political influence impinging on an agency and it may be able to use one to offset another. Finally, Figure 3 includes additional dotted lines flowing from both users and purchasers and from suppliers to political influence, as discussed below: users have numbers (votes) on their side, which are valuable in political markets but less so when interacting with bureau hierarchies. (Either suppliers or purchasers of the agency may well be other public agencies. While this usually does not change the basic analytic external assessment task that the agency faces, it does make it more complex when it occurs. As discussed in the paper, public agencies (including suppliers and purchaser agencies) have more multidimensional objective functions. This is beyond the scope of this paper.) 


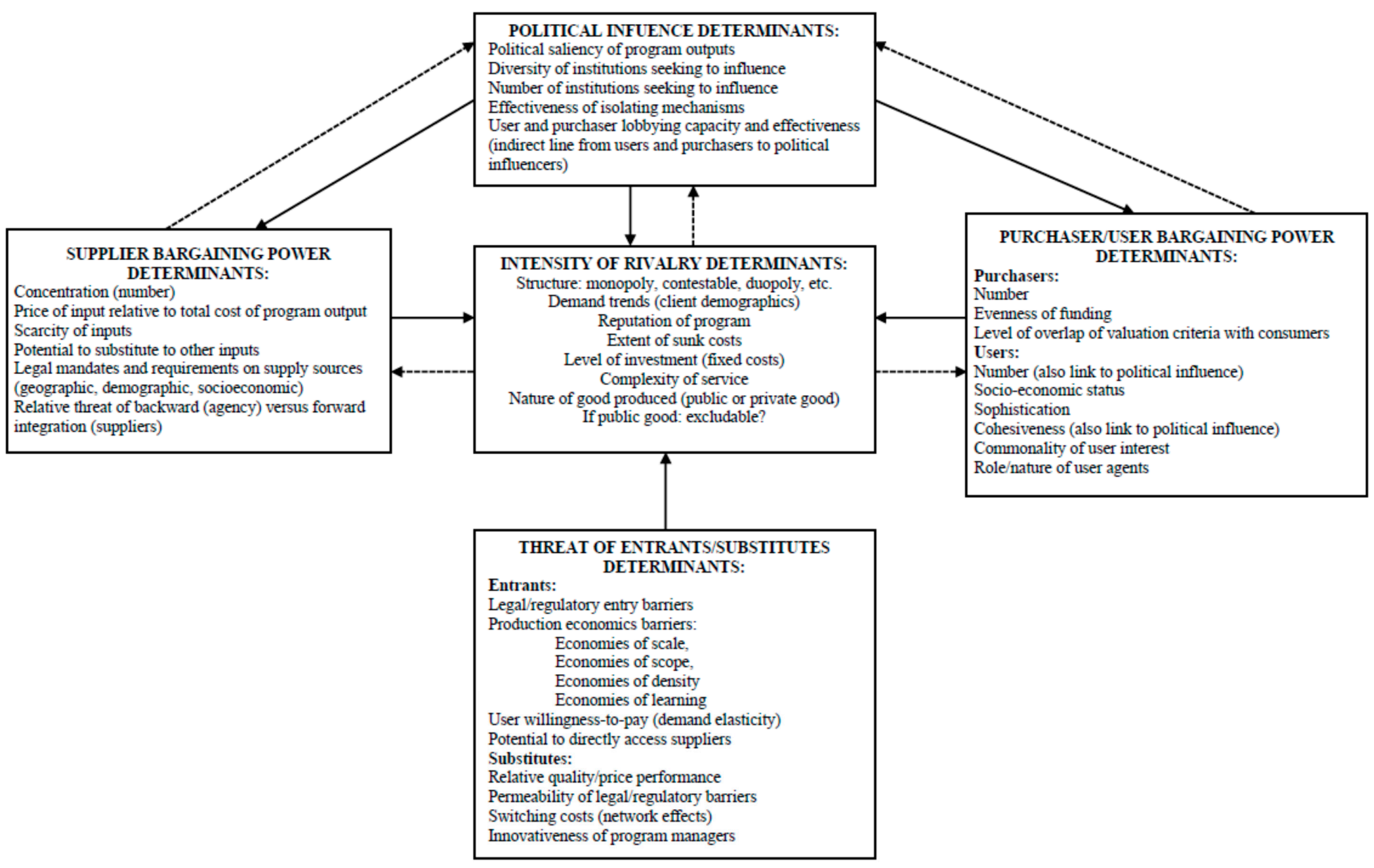

Figure 3. PASA External Forces Analysis. 


\subsection{Supplier Bargaining Power}

The role and analysis of supplier bargaining power is directly applicable to public agency programs. It is relevant because public agency suppliers have bargaining power: "Powerful suppliers capture more of the value for themselves by charging higher prices, limiting quality or services, or shifting costs to industry participants" [90] (p. 82). Public executives (like private sector executives) face numerous input suppliers that they must bargain with. In the public agency context, the concept of "power" and "powerful" inevitably encompasses both economic and political actors. The extent of economic or pricing bargaining power of suppliers matter because most public agencies purchase many of their factor inputs, including labor, land, and equipment from profit-maximizing supplier markets. There is some evidence that at least some public agencies bargain relatively poorly with suppliers over input prices [95-97]. An analysis of supplier bargaining power is necessary because the degree of competitiveness of supplier markets (and the resulting bargaining power of participants in the supply chain) varies widely across agency supply markets and even across programs within agencies [98-100]. Assessing the economic bargaining power of suppliers is usually somewhat easier than assessing the bargaining power of other external forces because most agency transactions with suppliers are "monetized", whether in the form of wages and salaries, computer and equipment purchases, or whatever. As a result, the (social) opportunity cost of these inputs can be estimated even when prices are not determined in competitive markets and price does not equal social marginal cost.

However, some public agency supplier transactions may not be monetized: a separate government agency, for example, may allocate land and buildings to the agency by fiat and without rental payments or formal accounting of the opportunity cost of these resources. In these cases, bargaining between the agency program executives and the suppliers is over the quality and quantity of inputs rather than their price and quality. Because of the higher ratio of non-monetized inputs, the concepts of bargaining power (and "political influence barriers" as discussed below) in the public agency context are more multidimensional and complex than in most equivalent private sector markets [101,102]. Specifically, in the absence of monetization, bargaining power has "political" as well as economic dimensions. Given these realities, agencies have to engage in better bargaining strategies to reduce the bargaining power of suppliers and cannot simply rely on more specialized purchasing agencies [103].

\subsection{Threat of Substitutes/Entry Barriers}

Many public agencies are subject both to the threat of substitutes and to the threat of entry because either entry or substitution is feasible. The threat of substitutes occurs when: "A substitute performs the same or a similar function ... by a different function [90] (p. 84). Substitution is often the greater threat to public agencies because while governments and their regulatory agencies can anticipate conventional entry and forestall it by law or regulation, it is more difficult to anticipate and forestall radical technologically based threats. These can seriously erode or destroy the viability of a public program [104]. Radical substitute technologies, for example, potentially allow current users to bypass an agency through "self-service" $[105,106]$. In many technologically dynamic markets, it is pointless to analytically distinguish between substitutes and new entrants. Public library systems, for example, have experienced a multipronged entry/substitutes threat, with the rapid diffusion of the Internet, the Worldwide Web, digitization and electronic publishing [107-109].

In some cases, even conventional entry is possible in the absence of comprehensive legal barriers to entry. These legal barriers may currently limit the entry of either for-profit firms, or non-profits. Even here, international agreements may limit the longer-term viability of these barriers to entry. However, not all public agencies have a legal and enforceable monopoly. Entry may simply have not been viable for rivals to enter under the existing technological regime. With the advent of new cost-lowering technology, the threat of entry becomes real. Entry, and even the threat of entry (a form of contestability), can seriously erode strategic autonomy and induce strategic reactions. 


\subsection{Citizen, Taxpayer, Resident, Purchaser, User, Client, Patient Bargaining Power}

In the competitive force model, the degree of customer (or buyer) bargaining power is crucial: "Powerful customers - the flip side of powerful suppliers-can capture more value by forcing down prices, demanding better quality or more service (thereby driving up costs), and generally playing industry participants off against one another, all at the expense of industry profitability" [90] (p. 83). This force is equally crucial in public agency analysis but requires some modification and amplification when used for public agency analysis because the meaning of "customer" is generally more complex in the public sector [110]. Two factors drive the added complexity: the frequent division between users and purchasers (buyers) and, relatedly, the high degree of variability in public agency user pay regimes [111]. In the public sector, "customers" have many different labels depending on the agency, program or service, including: citizens, taxpayers, residents, purchasers, users, clients, and patients. In most private sector industries, users mostly make the purchasing decision, although in in private sector markets with asymmetric information, users also employ third party purchasers [112]. The distinction between users and purchasers in some public agencies can be stark and create serious strategic challenges, especially if agency executives take efficiency seriously. In the most extreme form of bifurcation in public agencies, users (say prison inmates) do not participate in the purchase decision. Although sometimes it is useful to lump public agency users and purchasers together as "consumers" for semantic simplicity, it is almost always a bad idea for analytic and strategic purposes.

Especially under full bifurcation between users and purchasers, purchasers are more strategically important than users [113]. Purchasing authority confers greater bargaining power than does use. This is not to say that users cannot exercise some indirect bargaining power as the dotted line in Figure 3 indicates. (These indirect lines to political influencers could be included everywhere, but the connection is most important here.) The actual bargaining power of non-purchasing users depends on both their motivation to interact with agency executives and on the nature and extent of their resources, cohesion, and organizational skills. For programs where users do not "value" the service on all the same dimensions as purchasers, they only have motivation to exercise bargaining power on dimensions they value. For example, drivers convicted of driving under the influence (DUI) offenses that are required to participate in a detoxification program may not value the rehabilitative quality of their treatment, although they are likely to value the cleanliness of the treatment facility. In contrast, purchasers are likely to value rehabilitation highly, but may be prepared to sacrifice high levels of cleanliness. In practice, the valuation overlap between users and purchasers varies widely on a program-by-program basis [113].

Purchasers vary widely in their strategic interests and, therefore, in what they are interested in bargaining over. In some cases, these purchasers are central budget control agencies. In other cases, purchasers are other government "line" agencies. Purchasers are inevitably in some form of exchange relationship with the agency (as, of course, are users), but the leverage points in these purchaser relationships can vary widely. Budgetary and fiscal control agencies are typically primarily concerned with controlling or reducing payments to the agency and are not directly interested in bargaining to influence missions or policies, unless it directly affects total purchase expenditures. Line-agency purchasers, on the other hand, often seek to influence program policies, if only to indirectly influence purchase prices. To the extent that purchasers are concerned with the agency's strategies, their concerns may mirror those of users, or represent an independent demand agenda. For the agency, the demand side analysis of a given program is strategically more complex in the presence of multiple purchasers with differing demands and differing demand elasticities. This does not mean that purchasers are necessarily an important external force in any given context. The political influence force (below), manifested through a specific legislative committee often has greater bargaining leverage than purchasers. In sum, from a strategic perspective, it is critical for public executives to understand the extent to which users and purchasers overlap in their criteria for valuing a given agency service.

Agencies and programs vary widely in the degree to which they try to get users to pay for services. Road usage illustrates this variability. Most road users pay nothing directly. In contrast, toll road users 
may pay above or below the social marginal cost of use (the social efficiency criterion). So, users may either provide none, some, most, or all, of a transportation agency's revenue. Public agency full-cost (or more) pricing is variable: it is more common for state-owned enterprises (SOEs), corporatized entities [114,115] and special districts (in the U.S.). In addition, even where users do pay a significant percentage of service costs, they often do so through, or with the advice of, agents (as in the private sector). These purchasing agents typically have stronger bargaining power than individual purchasers because of greater concentration and less information asymmetry (including more knowledge of other government agencies or non-profits that could supply the equivalent service or provide a viable substitute.

If users contribute a high percentage of revenue to a program's expenditures and the agency has competitors, then even individual purchasers will have some bargaining power. Where users pay little or nothing, they may still be able to manufacture some indirect bargaining power. They can seek to strengthen their bargaining power by lobbying purchasers. They may also try to influence both the agency and purchasers by lobbying political institutions (as shown in Figure 3 by the indirect-dashed-"force line" from consumers to political institutions). Politically astute users (or agents that represent them) recognize when their service dimensions preferences do not match those of purchasers and they can leverage greater bargaining power by pressuring political institutions. Generally, individual users have only weak incentives to invest effort in interacting with agencies, except with respect to quality dimensions of the service that matter to them. This weakens the collective bargaining power of individual users, even though they are numerous (the "collective good problem". The emergence of social media has lowered their costs of organizing, but the public good problem is less debilitating in political markets. In political markets, influence effort usually involves less individual disutility: it is usually more fun to harangue vote-seeking politicians than to complain to stonewalling bureaucrats. The vote-seeking politician is more like a firm that has to satisfy paying customers

In sum, analysis of the bargaining leverage of both purchasers and users is a central part of external analysis.

\subsection{Intensity of Rivalry (Whether Actual Competition or the Threat of Contestability)}

In competitive forces analysis, the intensity of rivalry is usually the most important force and is represented as the "central" force. Figure 3 maintains this convention for public agency analysis, although direct competition is quite often not the most important force for PASA external analysis, most obviously when an agency has a de jure or de facto monopoly. Monopoly, of course, also occurs in the private sector-many shareholder-owned electrical, gas and water utilities, for example, are monopolies.

Strategically, the contestability of a given program monopoly can be as important as the current state of competition that it faces. In many cases, an agency's program monopoly status is foreseeably secure: it is not contestable. The basis of an agency monopoly, such as the collection and analysis of basic national demographic information, may be based on the existence of significant economies of scale. At the limit, average cost declines continuously over output, resulting in natural monopoly [75] (pp. 97-103). Many public programs also deliver pure collective goods where the public cannot effectively be excluded from consumption [75] (pp. 72-91). These collective goods services may also exhibit natural monopoly cost and demand conditions. Many agencies provide services for redistributive purposes and users cannot manifest market demand (although, of course, there may be significant need).

In the absence of watertight legal barrier to entry, many programs do not have effective monopolies that can be expected to endure over time. Many agencies, especially at the regional and local level, provide services that exhibit neither significant economies of scale nor collective good characteristics, that is, they deliver private goods that are both rivalrous in consumption and excludable. Structural cost factors alone do not foreclose competition that might enhance efficiency from not-for-profit or even for-profit competitors. Many local services are delivered by "mixed contracting" where a public 
agency competes to some extent against contracted service. In the U.K. many public services are subject to compulsory competitive tendering [93]. Some sectors in some countries encourage or allow competition between public organizations while not allowing for-profit competition [116,117]. Other sectors, such as nursing home provision, exhibit significant competition between public sector agencies, for-profit firms, and not-for-profits [118]. One reason that many public agencies, especially corporatized ones, face increased competition is that they are increasingly being required to charge prices for their services that meet or exceed the cost of provision [114]. If agency prices are forced to approximate the marginal costs of delivery, then an agency become subject to competition or the threat of entry by private-sector competitors or non-profits [119]. Increased competition is also certainly a possibility in the presence of technological change that reduces minimum efficient scale and erodes entry barriers resulting from natural monopoly. Intensified competition can also result from broader socioeconomic change that alters demand conditions: public schools face increasing competition from private schools because of changing preferences, wealth increases, and a variety of other factors. In all of these cases, public agencies face more direct competition. As the acid test is increase in social efficiency, this does not mean that competition is always good [120-122], but whether good or bad it is always strategically important as it reduces strategic autonomy and narrows an agency's feasible alternatives. Competitors provide alternative sources of supply for both purchasers and users; this increases the bargaining power of purchasers and (sometimes) users. Furthermore, competition usually provides political institutions with greater information about the agency's behavior and performance. Reduced information asymmetry usually gives these political institutions greater influence and leverage.

Second, even in the absence of direct competitors, many agencies face the possibility that some other agency could replace them in providing some, or all of their services, albeit perhaps at some net incremental cost to purchasers. Contestability or "latent" redundancy can provide incentives for an agency to change its strategy [123-125]. Many sub-national government agencies face quite credible threats of replacement [126]. In these circumstances, consumers can relocate and mobility functions as a form of contestability $[127,128]$. This is particularly pertinent if an agency has industrial consumers that are highly price (tax) sensitive.

In sum, the concept of rivalry is conceptually relevant even in many monopoly situations because the degree of contestability is often more important in determining the degrees of strategic freedom than is direct competition. The conceptually important alternative competitive states that drive PASA are: (1) monopoly with little contestability; (2) monopoly, but with significant contestability; (3) competition from other government agencies or not-for-profits, and (4) competition that includes for-profit firms. An agency with a monopoly and low contestability has numerous degrees of freedom.

\subsection{Political Influence Barriers}

Figure 3 shows the addition of political influence barriers as a distinct force (unlike in competitive forces analysis). This distinguishes PASA from business unit analysis. Many legislative and executive branch entities seek to influence public agencies. Some of these attempts have some normative legitimacy, many others much less so. As with other external forces, agencies can seek to insulate themselves from influences $[129,130]$. They can do so if influence barriers can be altered by agency strategic actions.

Generically, two factors are particularly important in determining the aggregate level of political influence barriers: the institutional ownership structure of the agency (the de jure property rights regime) and the permeability of the institutional ownership structure (the de facto property rights regime. For the purposes of external analysis, the focus is primarily on assessing the combined level and sources of influence barriers. Some agencies have constitutional or quasi-constitutional protection from political influence. In stable institutional environments, these formal barriers insulate agencies from overt political influence. In democracies, state-owned (SOE), mixed enterprises (private corporations in which government has some shareholding position) and "corporatized" entities [114,131] are 
endowed with quite high formal barriers to political influence. Line government agencies usually have lower formal barriers to political influence. Agencies that work directly for the executive or legislative branches have almost no barriers. In many countries, Quangos of various kinds have become much more prevalent [114]. Corporatization in the U.S. now encompasses a vast array of independent agencies. The Public Company Accounting Oversight Board (PCAOB) mandated by the Sarbanes-Oxley Act (http://www.soxlaw.com/) is an interesting example that has significant barriers to political influence built into the enabling legislation. Even though it is a public agency, this legislation explicitly states that employees are not employees of the federal government and that they may be paid compensation equivalent to private sector self-regulatory bodies [132]. All public companies are subject to a mandatory "Accounting Support Fee" which is payable directly to PCAOB and which essentially covers all its expenditures [132]. This ensures fiscal autonomy, if nothing else.

However, the institutional ownership structure alone is not the only factor determining political influence barriers. The formal barriers to influence are more or less permeable. Politicians, at various jurisdictional levels have a wide range of indirect methods to try and permeate, circumvent, or simply overpower formal ownership structure barriers to influence [133-135]. There is evidence, for example, that U.S. state-level politicians have gained considerable influence over federal agencies even though they have no formal authority over them [136-138].

The purpose here is not to explain the complete PASA framework so many important aspects of external analysis are not discussed here. For example, it sometimes makes sense to consider an additional force (such as an important interest group or a complementary public organization).

\section{Internal Analysis}

Conceptual frameworks for performing internal analysis of private sector organizations are well known [43,139-142]. However, as with external analysis, many aspects of these frameworks do not transfer well to public agencies without modification. Again, this lack of transferability fundamentally relates to goals. A primary focus of most firm internal analysis is on how to increase profit through more efficient internal processes that generate or increase rent (or more correctly quasi-rent) capture or extraction. The VRIO (resources that are valuable, rare, imperfectly imitable and that the organization can capture) model, for example, focuses on the more efficient use of assets to create rents for owners [140]. Although these models offer many insights that can be applied to public agencies, the dominant focus on rent extraction is not normatively appropriate when adopting a public agency social efficiency perspective [143]. The value chain model (Porter) and related models that disaggregate this process into activities also offer many useful insights to structure thinking about the public agency value creation process. Again, though, these components of the value creation process must be adjusted to the different goals and strategic needs of public agencies.

There is now an emerging literature that explicitly addresses public organization internal analysis [26,144-148]. For strategic purposes, the process of categorizing and assessing assets is essentially an inventory analysis, also metaphorically described as "stock", "hardware" or "balance sheet" analysis $[149,150]$. The complementary task of assessing the value creation process is best conceptualized as a "flow", "software" or (social) "income statement" analysis [151]. For many reasons, an analysis of public agency social value creation is more analytically valuable than is inventorying [62]. These reasons include the fact that each agency deploys a unique bundle of evolving knowledge and problem solving expertize [150]. As a result, agencies cannot simply engage in mimetic behavior with respect to trying to improve their value creation process as they possibly could by observing asset inventories [152]. (This is not to say that considering learning from "best practice" is not a good idea; however, it is rarely enough). But a lack of consensus on the appropriate meaning of public value is a significant barrier to analyzing the social value creation process in public agencies and to easy imitation. But, understanding the social value creation process is central to good PASA because it is the foundation for assessing the need for normatively based strategic change in public agencies. Therefore, an internal analysis that focuses primarily on value creation analysis is likely to 
be most able to provide a comprehensive and dynamic internal assessment that can, in turn, flow into a comprehensive strategic analysis (Figure 1).

\subsection{Value Creation Analysis}

For some public programs, the value creation (or destruction) process can often be best disaggregated and analyzed by thinking of it as a sequential "chain" of steps. Thompson [153] called these processes "long-linked" technologies. Porter [154,155] popularized this process using value chain language. Not surprisingly, this metaphor for the production process implies a clear temporal sequencing of activities. Many public hospital surgical procedures, for example, can be straightforwardly modeled as a chain. Patients enter the system via a number of preparatory administrative and medical steps ("inbound logistics"), then are treated through a number of sequential operating theater steps, such as sedation and surgery ("operations"), and then exit the hospital through another series of "post-op" administrative and medical steps, such as recovery and discharge ("outbound logistics"). The division of the chain into inbound logistics, operations and outbound logistics represents the simplest disaggregation of the value chain into three activity steps.

Thompson [153] presented two other kinds of technological processes that may better model a given "production" process, especially those with important service and intangible elements. These have been subsequently adapted for strategic management purposes [156]. As a result, where appropriate, the value creation process can be analyzed using at least either the value chain, the "job shop" or the value "network" metaphor or some combination of the three $[153,156]$. However, although each of these value creation models are used in private sector analysis, there is much less use of them in public agencies [157,158]. Given the uniqueness and complexity of some public agency production, it is also quite possible that additional metaphor/models would be useful in specific agency contexts. For example, some agencies primarily create social value by oversight monitoring and regulation third-party organizations that deliver services. This regulatory "production" process does not fall easily into the chain, modular assembly or platform production technology frameworks. In contrast to the chain, which can be intuitively understood as a horizontal process, regulation is more intuitively thought of as a vertical and hierarchical (principal-agent) process. It is important to emphasize that activity disaggregation and value creation analysis are applied tasks and workable disaggregation can sometimes be best accomplished by combining elements of all three. But, the potential use of a combination raises the question: when does a combinatory exercise turn into a Rube Goldberg machine that would be better served with a new construct?

For a variety of reasons, I retain the chain terminology below, but henceforth use "modular assembly" rather than shop, and "platform" rather than net. The chain metaphor works best with sequential and linear activity processes that are divisible into inbound logistics, production and outbound logistics activities. The modular assembly metaphor is based on the idea of the repair shop where each "repair" problem is unique, but many or all of the same modular elements could be used to address the specific problems: each problem is unique, but solutions can be entirely or mostly build from standard analytic components and assembly heuristics. Each article a research professor at a public university writes is at least somewhat unique (hopefully), but the core components (microeconomic concepts, logit regression analysis, action research, etc.) are not. Modular assembly works best for less linear, more iterative production processes. The platform metaphor places the producing agency at the center of, and between, some exchange process (for example, between the supply of something and the demand for something): that is, acting as an intermediary. "Platform" is thus a metaphor for an intermediation or brokerage process. In the public agency context, intermediation is most likely to be socially valuable when the desired exchange would not sustain market-like prices (that is, there is some "market failure") or when price-based exchange is not feasible or is even disallowed on equity grounds [159-161]. Thus, the analysis focuses on the set of activities required to analyze the platform for intermediation value creation process [162]. Consequently, the analysis is potentially concerned with providing the platform, reconfiguring it to better serve 
the needs of the intermediate agency or the exchangers or eliminating it where the market failure has ameliorated [158]. The platform production process is different from chain or modular assembly processes because by its nature the public agency platform must itself provide value and it can only do so by providing at least some value to both sides (the "double commitment" problem) of the platform. Neither side has an incentive to voluntarily join and actively use a given platform unless the participants on each side are convinced that they will derive value from the platform and that the "other side" participants will as well.

Table 1 summarizes the primary characteristics of the chain, modular assembly and platform processes and summarizes when each fits best and when combinations might work. In the spirit of making a livelihood, the question is which one works better?

Because, as far as I am aware, these alternative framings have not been articulated in a public agency context, Figure 4 summarizes how the value creation process of an agency platform production process might be framed and analyzed. The summary emphasizes that platform value depends on a number of distinct two-way and three-way relationships between the platform provider (the agency) and the two sides. For illustrative purposes, in Figure 4, information or expertise providers (for example, academics) make their papers available electronically and information consumers (such as graduate students) read these pearls of wisdom. Information providers and consumers can connect through many platforms, but a common academic platform is Google Scholar.

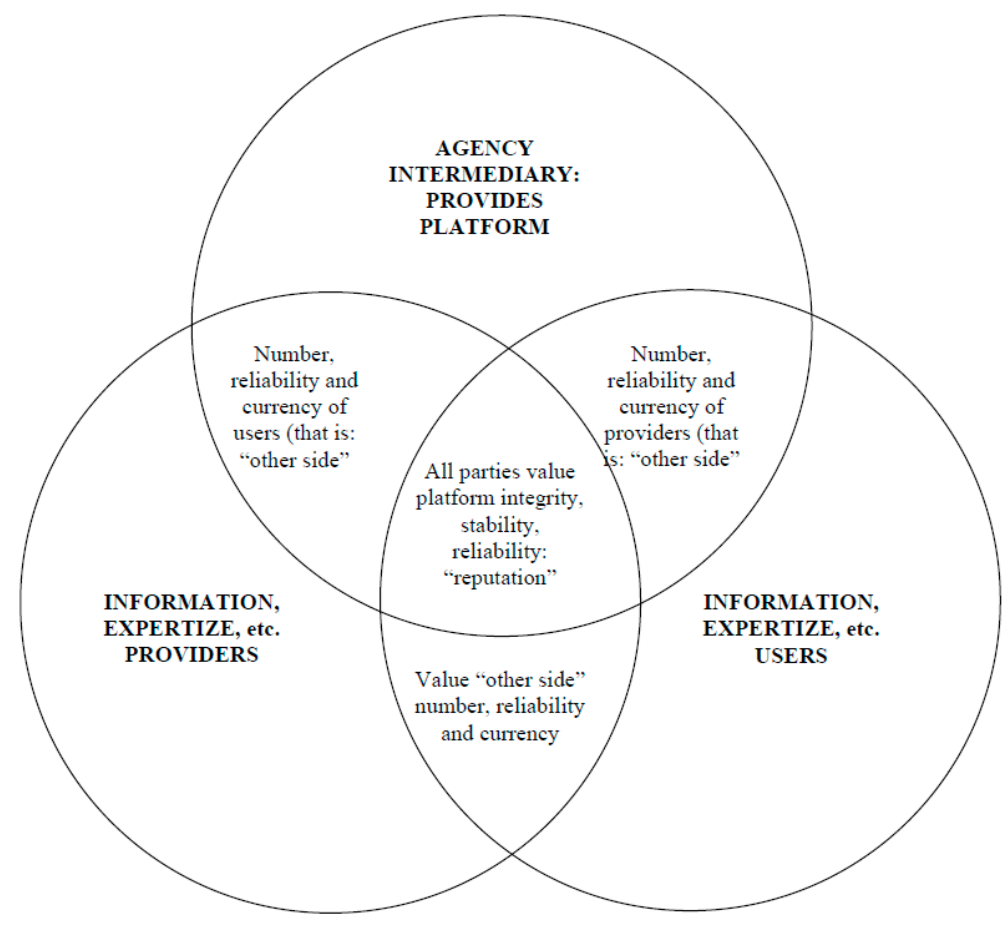

Figure 4. Illustrative Platform Value Creation Model/Metaphor and the Various Value Intercessions.

There is one caveat to the use of any of these disaggregated value creation analysis processes. Given that their reference point is a current production process, they primarily offer the potential for incremental activity level improvements in value creation; for example by designing a lower cost step in a sequence or eliminating a current step. Such changes can deliver impressive social benefits in aggregate [163]. But these aggregating-the-increments processes offer less opportunity for overcoming organizational core rigidities and thinking about more radical innovation that is not (potentially) embedded in current routines [164]. Agencies vary considerably how they manage innovation and, consequently, in their ability to think outside the incremental value creation box [165]. 
Table 1. Three PASA Value Creation Metaphors/Models for Internal Analysis.

\begin{tabular}{|c|c|c|c|c|c|c|c|}
\hline Metaphor & Technology & $\begin{array}{l}\text { Change/Reduce } \\
\text { Cost Process }\end{array}$ & Works for ... & $\begin{array}{l}\text { Public Agency } \\
\text { Example }\end{array}$ & Combinations & Combo Example & Comments \\
\hline Chain & Long-linked technology & $\begin{array}{l}\text { Look to cut out } \\
\text { chain links }\end{array}$ & $\begin{array}{l}\text { Products and } \\
\text { some services }\end{array}$ & $\begin{array}{l}\text { Permit approval, } \\
\text { processing and } \\
\text { payment }\end{array}$ & $\begin{array}{l}\text { It is increasingly } \\
\text { possible to combine } \\
\text { chain and modular by } \\
\text { within chain step } \\
\text { insert module features } \\
\text { (mass customization }\end{array}$ & $\begin{array}{l}\text { In surgery operations } \\
\text { chain stage, provide } \\
\text { custom blister packs of } \\
\text { instruments, meds, etc., } \\
\text { that is, chain/modular } \\
\text { combo }\end{array}$ & $\begin{array}{l}\text { Common, but } \\
\text { electronic communication } \\
\text { encourages more combos }\end{array}$ \\
\hline Modular assembly & $\begin{array}{l}\text { Intensive technology } \\
\text { Components on real or } \\
\text { virtual "shelves". } \\
\text { Focus on (almost) unique } \\
\text { problem solving }\end{array}$ & $\begin{array}{l}\text { Stock inventory of } \\
\text { many potential } \\
\text { components. } \\
\text { Modularization helps } \\
\text { standardize each } \\
\text { unique problem }\end{array}$ & $\begin{array}{l}\text { Differentiated or } \\
\text { customizable services } \\
\text { or products. Needs } \\
\text { minimum volume to } \\
\text { be worth } \\
\text { modularization effort }\end{array}$ & $\begin{array}{l}\text { Policy analysis, } \\
\text { statistical analysis, } \\
\text { political analysis }\end{array}$ & & $\begin{array}{l}\text { In policy analysis, } \\
\text { combine modular } \\
\text { assembly and platform by } \\
\text { holding inventory of } \\
\text { individuals with specific } \\
\text { skills: (economists and } \\
\text { anthropologists) }\end{array}$ & $\begin{array}{l}\text { Common, but with } \\
\text { "experience curve" (more } \\
\text { volume over time) adds } \\
\text { chain elements }\end{array}$ \\
\hline Platform & $\begin{array}{l}\text { Web, brokerage, net, } \\
\text { (inter) mediating } \\
\text { technology. Minimum is } \\
\text { 2-sided platform with } \\
\text { agency platform, but can } \\
\text { be many sided. }\end{array}$ & $\begin{array}{l}\text { Reconfigure } \\
\text { intermediation. } \\
\text { Add new } \\
\text { intermediation or cut } \\
\text { out, or reduce, current } \\
\text { intermediation by } \\
\text { regulatory change }\end{array}$ & $\begin{array}{l}\text { Intangible services: } \\
\text { e.g., information } \\
\text { provision and } \\
\text { receiving platform }\end{array}$ & $\begin{array}{l}\text { Job matching } \\
\text { between } \\
\text { employers and } \\
\text { jobseekers. } \\
\text { Emergency } \\
\text { notification }\end{array}$ & $\begin{array}{l}\text { Possible to combine } \\
\text { module and platform } \\
\text { through mass } \\
\text { customization }\end{array}$ & $\begin{array}{l}\text { In employment matching } \\
\text { increase customization } \\
\text { features that combine } \\
\text { platform and } \\
\text { modular assembly }\end{array}$ & $\begin{array}{l}\text { Have to provide different } \\
\text { value proposition to each } \\
\text { side of the "market". } \\
\text { But if no value to either } \\
\text { side, platform withers }\end{array}$ \\
\hline
\end{tabular}




\subsection{Estimating Value Creation: Either Currently or under Potential Feasible Alternatives}

Value creation analysis is difficult because it requires both an analysis of current program value creation and the potential for greater value creation when considering feasible alternatives. The former (current value creation) is considered at this stage of the strategic analysis, while the latter (potential value creation) under the alternatives is considered later.

The first way of thinking about value creation in the public agency focuses on the cost of an activity and assessing the potential for cost reduction, holding the current level of output constant. While, as explained below, this cost focus can be criticized as being reductionist, a cost focus has the advantage that it can usually be estimated and measured. The minimalist justification for activity cost analysis from a social efficiency perspective is that cost reduction is rarely normatively inappropriate, if output is really held constant [148]. The ideal cost goal is cost "minimization", but as there is seldom a totally convincing "minimum cost" counterfactual available, a focus on cost reduction is often a practical and achievable focus [166]. Sometimes, cost reduction can be analyzed in terms of simply eliminating an activity step (a link in a chain or a modular element) in an existing service, as this kind of cost reduction is often the easiest to measure and quantify. More frequently, however, it means reconfiguring the current activity steps in a lower cost manner: that is, some kind of "business process reengineering" (BPR) [167] applied to public agencies [147,168-171]. The introduction of electronic communication systems (for example, the use of email) facilitates many such BPR cost reductions, with each individual reconfiguration sometimes having only an almost imperceptible impact on aggregate production cost.

An important reason cost reduction analysis is often enough is that the major benefit of many public programs is the "avoided cost" of some harm (e.g., [172-175]). So, for example, "avoided cost" benefit categories for specific energy investments might include "Avoided Generation Capacity", "Avoided Transmission Losses", "Net Avoided Outage Costs", and "Net Avoided Green House Gasses” [175].

The second way to assess value creation is to observe quality or quantity changes (more generally, social benefits changes) while holding cost constant. This approach is often most plausible and convincing to third parties when theses benefit changes can be monetized, or at least quantified.

Third, and most comprehensively, cost-benefit analysis (CBA) looks at potential changes to both costs and benefits [32]. Here, the CBA concept is used broadly and is not limited to analyses which seek to "monetize" (that is, put a dollar valuation on) all impacts that are valued positively by residents of the jurisdiction.

In practice, it is sometimes difficult or impractical to monetize all impacts that accrue to jurisdictional residents. Instead, the analysis monetizes as many impacts as possible and computes the net present value (NPV) of those impacts, and does not quantify some intangible impacts. Boardman and Vining [36] refer to this type of analysis as "incomplete CBA". Given this, CBA is as applicable to agency social programs as much as to other kinds of programs. Doing incomplete CBA does not mean that non-quantified impacts should be ignored. Indeed, Arrow et al. [176] argue that analysts (and decision-makers) should consider factors that defy quantification. Where there are multiple non-monetized impacts, Nijkamp [177] (p. 147) suggests that "[t]he only reasonable way to take account of intangibles ... seems to be the use of a balance with a debit and credit side in which all intangible project effects are represented in their own dimensions." However, considerable progress is being made on predicting the impacts of social policies: for example, of the effect of early childhood lead exposure on childhood behavioral problems, teen pregnancy, aggression and adult criminal behavior [178]. This knowledge is central to potential agency policies to reduce exposure to lead. Thus, incomplete CBA, where most impacts are monetized but some remain measured qualitatively is a viable option. Additionally, in spite of their weaknesses both cost-effectiveness analysis (CEA) and cost-utility analysis (CUA) are often useful methods.

\section{Feasible Alternatives: The Importance of Being Autonomous}

A central role of those engaged in policy research is the presentation and discussion of superior policy alternatives, including those that might be implemented by a successor government that would 
be prepared to devote more resources to the program or devote more political capital to the program. Public executives engaged in strategic analysis, however, are, and must be, more concerned with feasible strategic alternatives, that is that are feasible within existing constraints, although it may be practical to consider some alternatives that are only feasible with, for example, some degree of external authorization, for example, requiring some degree of "user pay" [68]. Implicitly, deciding on the set of feasible alternatives is a metachoice process [27,179]. Agency leadership matters in shaping the perceived available alternatives [180].

But, reality matters too! Programs and agencies vary tremendously in their strategic degrees of freedom (autonomy), and therefore, in their ability to meaningfully change strategies. What drives the degrees of freedom or more broadly agency autonomy? Simplifying somewhat, Vining [44] argues that autonomy is a function of the combined extent of policy and fiscal autonomy (cf. [181]). Agency executives should be largely able to assess their autonomy after an assessment of external forces (summarized in Figure 1 and further disaggregated in Figure 3) and internal attributes (summarized in Table 1). Figure 5 summarizes four generic agency or program types and level of autonomy: autonomous programs (with both high policy and fiscal autonomy), golden-handcuff programs (high fiscal autonomy, but low policy autonomy), poor-but-free programs (high policy autonomy, but low fiscal autonomy) and indentured programs (with neither policy or fiscal autonomy). Of course, these quadrants represent archetypes. To emphasize this, the central circle represents "average" programs in terms of autonomy. Figure 5 also summarizes the conditions that characterize each quadrant and standard strategic implications and consequences of each quadrant location.

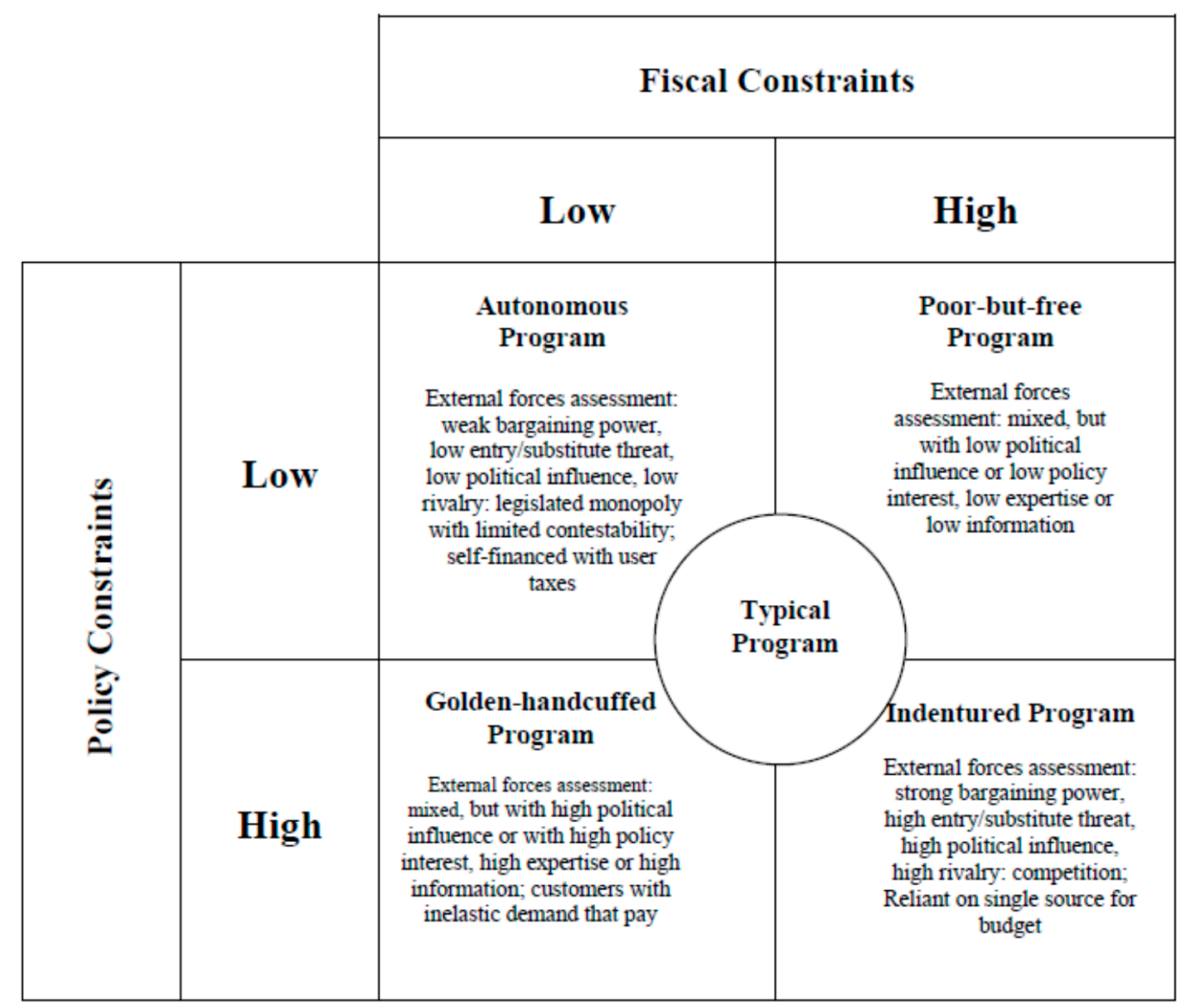

Figure 5. Typology of Program Autonomy and Different Degrees of Freedom.

\subsection{Autonomous Programs}

In terms of presenting an agency with a broad range of strategic alternatives, overall autonomy is desirable but hard to achieve. Formal or de jure agency independence is an important precursor in almost all cases, whether as a corporatized entity or other form of autonomous agency or 
as a state-owned enterprise (SOE). Other trademarks of autonomous programs are a legislated monopoly, broad or vague legislative mandates and highly specialized technical expertise or capabilities [182]. A legislated monopoly eliminates the need to respond to actual or potential competitors. Highly specialized expertise results in asymmetric information, which blunts effective political influence. Broad mandates provide formal room for policy innovation, while self-financing fosters fiscal autonomy. Formal authority to collect fees is valuable, especially if mandatory. It provides the ability to self-finance without external gatekeepers. There are several versions of self-financing. One financing model that provides fiscal autonomy is some form of endowment $[183,184]$. The U.S. Federal Reserve System (the "Fed") is in this enviable position of self-financing via its holdings of income-bearing securities. Fees on transplant listings largely self-fund the Organ Procurement and Transplantation Network [185]. In the U.S., various forms of "user fees" are an increasingly common method of funding regulatory agencies. In fact, these fees are more like taxes because government mandates require regulated parties to pay them. "The Fed, FDIC, OCC, OTS, and NCUA, for example, generate income through their regulatory activities ... [so] efforts to influence staffing or regulatory priorities are limited by the internal generation of the budget" [186] (p. 8). Similarly, PCAOB's mandatory accounting "support fee" and its technical mandate buttresses both its fiscal and policy independence. Following the 2008 financial meltdown, there were efforts to also give the U.S. Securities and Exchange Commission such fee-collecting authority but the provision was never enacted.

Agency executives with autonomous programs in their portfolio are in the enviable strategic position of having the power strategically to alter or negate at least some of the external forces that they face, so for executives of these programs the forces in Figure 3 actually flow in both directions. Agency executives can consider many forms of programmatic growth or expansion: whether in terms of targeting new consumer segments, new funding sponsors, geographic expansion of the program footprint or the development of new service within the program envelope. The U.S. Coast Guard, for example, has able to use its extensive strategic autonomy to expand into new program areas [187,188]. Corrêa d'Almeida and Klingner [189] argue that the Federal Emergency Management Agency was able to use its autonomy to effect innovative policies for a period under the leadership of James Witt (1993-2001), but then subsequently lost this autonomy and much of its effectiveness (see also [190]).

Ironically, autonomous programs that experience strategic failures are often given more, rather than fewer, resources! Security or emergency programs can "suffer" this fate. These programs have high financial autonomy because they face either no competition or at most only one. Additionally, because they possess highly specialized assets and capabilities, they generally face limited contestability [191]. These programs also tend to have high policy autonomy because the need for secrecy, the complexity of performance measurement, and the presence of significant isolating mechanisms all buffer them from most sources of political influence. However, autonomy raises the risk of drifting away from a focus on public value with some predictable consequences: hubris, a tendency to groupthink, the dominance of "yes-men," and endemic X-inefficiency [192-194].

\subsection{Indentured Programs}

In stark contrast to autonomous programs, programs with both low fiscal and policy autonomy can be characterized as indentured programs. Such programs and agencies get their strategies imposed on them by others in their external environment and are likely to be characterized as ineffective. Some critics, for example, have characterized the Federal Election Commission (FEC) as such an agency [195]. In the worst-case scenario-where an indentured agency has only one program - the agency has no strategic autonomy except to the extent that it can improve internal value creation "under the radar", most often by pursuing greater cost efficiency. However, few agencies are indentured for life as most agencies deliver multiple programs and, thus, have at least some minimal scope to either improve their efficiency or to gradually reshape their portfolio. Even if the agency's mandate does not allow it to completely exit from a program, or executives do not want to exit because of the public value delivered, it may still wish to redeploy internal resources to programs with more 
autonomy. This is more likely to be effective to the extent that budgetary supervision is incrementally oriented, thus allowing the creation of discretionary resources.

\subsection{Poor-but-Free Programs}

Poor-but-free programs are often those providing programs and services to "unloved" users. These users include the homeless, the mentally ill, the incarcerated, the addicted, and the illegal. Frequently, both purchasers and other actors in the external environment dislike expenditures on these programs as they garner few kudos or votes, while attracting much criticism if anything goes wrong. Poor-but-free programs are on a strict budgetary diet. But almost as a corollary, they have low political saliency unless (unusual) events draw attention to the programs (usually negatively), so executives usually have considerable policy autonomy. Many regulatory agencies, particularly those with an inspectorate role, are in this situation. For example, even after the Food and Drug Administration was allowed to charge pharmaceutical companies for expediting drug approvals (which clearly improved its fiscal autonomy somewhat), it was still underfunded given its policy mandate [196].

A generic strategy for poor-but-free program executives is to seek to increase fiscal autonomy, while retaining the current degree of policy autonomy. This is a delicate task because the two autonomies tend to offset. Messing with fiscal oversight tends to attract attention to agency policy and strategy. Strategies that lower costs along a program's value chain do not attract much external attention although they increase fiscal degrees of freedom [154,197]. One way executives can seek to increase fiscal autonomy is through aggressive bargaining over price with both suppliers and users, and, if possible, with funders over additional revenues. The latter effectively amounts to seeking higher prices. Historically, most public agencies have been poor at such bargaining, probably because public agency executives get few direct rewards from this unpleasant activity-they do not get to retain any of the fiscal residual, unlike many private sector executives. Provided the agency can retain the freed-up resources (not necessarily an easy thing to do), it can increase fiscal autonomy. Although it attracts some external attention, executives can consider "back-end" contracting-out [191,198] or low capital-intensive investments in cost reducing new technology.

\subsection{Golden-Handcuff Programs}

Golden-handcuff programs are somewhat unusual in that a high degree of fiscal autonomy normally also enhances the policy autonomy of a program's executives. However, policy freedom is formally constrained when agency or program legislative mandates are detailed and externally monitored [199,200]. Relative fiscal abundance occurs when powerful external forces are willing to bribe (and handcuff) agencies with high levels of resources or "blackmail" them by threatening to withhold or withdraw financial resources as the quid pro quo for policy and mission acquiescence. On a number of occasions, for example, Congress has been generous with funds for some specific weapons programs (such as the V-22 Osprey) even though the Defense Department may not have particularly wanted them [201]. In some cases it is unclear whether the funds are a bribe or blackmail! Of course, Anglo-Saxon kings that agonized about paying Danegeld faced the same self-doubt [202].

This quadrant sometimes can also feature controversial and high profile programs, in such areas as family planning and medical research. These programs often receive quite generous resources for their existing mission, as they have powerful purchasers and users who can exert pressure on other actors in the broader external environment. Such programs have high political salience and attract a high level of political influence and monitoring from both opponents and supporters.

In spite of policy constraints, fiscal autonomy is valuable in its own right because it can empower some policy innovation, provided it is low profile and not controversial. Cost-lowering technological investment can fall into this category. Fiscal autonomy can also facilitate cross-subsidization of the development of new experimental services or extension of services to higher-cost users [203]. At the very least, fiscal autonomy enhances budgetary certainty and allows executives to implement more stable policy [204]. 
What is wrong with golden handcuffs? It is very easy for both executives and employees to drift away from a concern with social value. As a consequence, both can succumb to cynicism or laziness and to focus on generating higher salaries, more perquisites, the quiet life, gold plating, and even corruption - in other words, to fall prey to particularly pernicious forms of inefficiency.

It is important to stress again that both policy and fiscal autonomy must be analyzed at the program level, as programs within an agency portfolio can vary greatly in terms of autonomy [17]. Analysis of the portfolio of all agency programs, in contrast, is analogous to private sector corporate strategy and requires different strategic tools that are beyond the scope of this paper.

\section{Conclusions}

The quality of public management matters and so does the quality of public agency strategic analysis. But, in practice, both the internal characteristics of the particular program and the nature of the external environment it faces (including its competition or contestability) constrain agency choice and change. Together, therefore, these forces and internal capabilities largely determine a given program's degrees of strategic freedom and its set of feasible strategic alternatives. This is the strategic imperative. But, program and agency strategic choice (or more accurately, metachoice) should be constrained by a normative imperative: only consider, select and recommend those strategies that have potential to improve social efficiency. This is an important normative imperative because not all meanings of public value are close to equivalent to a social efficiency meaning: some meanings of public value fail this test and are not as normatively appropriate. Social efficiency is normatively appropriate because it assesses and seeks to increase aggregate jurisdictional welfare and it does not privilege any one intra-jurisdictional group or individual over any other. Thus, "unorganized" or inarticulate members of the jurisdiction are given the same weight as organized interests (so called "stakeholders"). Ideally, the use of the social efficiency criterion (through cost-benefit analysis or practical substitutes where it makes sense) also balances the welfare of present jurisdictional members against those of future jurisdictional members (where long-lived investments make an intergenerational perspective the appropriate one). The search for increased social efficiency is both difficult to achieve, and difficult to explain to external environment actors, because any positive increment to social value often consists partially, or totally, of avoided costs: whether less crime, lower morbidity or reduced carbon emissions $[80,205]$. Appropriate PASA is unique because it provides a framework that combines practical strategic action with achievable social purpose through the strategies of public agencies.

A final point: PASA is most importantly a framework for agency strategic thinking rather than for strategic writing (not that there is anything wrong with the latter). External environmental volatility inevitably changes PASA. In volatile and disruptive environments, the two page analysis with five summary figure/tables may well be more useful to executive decision making than a two hundred page analysis delivered nine months later when everything has changed in the environment.

Acknowledgments: The author would like to thank Ulrike Radermacher, Mark Selman, David Weimer and Mark Wexler and two anonymous referees for very helpful comments and the Social Science and Humanities Research Council Canada (SSHRC) for financial support. The usual caveats apply.

Conflicts of Interest: The author declares no conflict of interest.

\section{References}

1. Meier, K.J.; O'Toole, L.J. Public Management Quality and Organizational Performance: The Effect of Managerial Quality. J. Policy Anal. Manag. 2002, 21, 629-643. [CrossRef]

2. Andrews, R.; Boyne, G.A.; Enticott, G. Performance Failure in the Public Sector: Misfortune or Mismanagement. Public Manag. Rev. 2006, 8, 273-296. [CrossRef]

3. Black, S.; Lynch, L. How to Compete: The Impact of Workplace Practices and Information Technology on Productivity. Rev. Econ. Stat. 2001, 83, 434-445. [CrossRef]

4. Bloom, N.; Genakos, C.; Sadun, R.; Van Reenen, J. Management practices across firms and countries. Academ. Manag. Perspect. 2012, 26, 12-33. [CrossRef] 
5. Andrews, R.; Boyne, G.A.; Walker, R.M. Strategy Content and Organizational Performance: An Empirical Analysis. Public Adm. Rev. 2006, 66, 52-63. [CrossRef]

6. Bryson, J.; Berry, F.; Yang, K. The State of Public Strategic Management Research: A Selective Literature Review and Set of Future Directions. Am. Rev. Public Adm. 2010, 40, 495-521. [CrossRef]

7. Dollery, B. The Influence of Economic Theories of Government Failure on Public Management Reform. In International Handbook of Public Management Reform; Goldfinch, S., Wallis, J., Eds.; Edward Elgar: Cheltenham, UK, 2009; pp. 17-40.

8. Gormley, W.; Weimer, D. Organizational Report Cards; Harvard University Press: Cambridge, MA, USA, 1999.

9. Vining, A.; Weimer, D. Policy Analysis. In International Encyclopedia of the Social E Behavioral Sciences, 2nd ed.; Wright, J.D., Ed.; Elsevier: Oxford, UK, 2015; Volume 18.

10. Niven, P. Balanced Scorecard: Step-by-Step for Government and Nonprofit Agencies; John Wiley and Sons: Hoboken, NJ, USA, 2008.

11. Madsen, D.; Slatten, K. The Balanced Scorecard: Fashion or Virus? Adm. Sci. 2015, 5, 90-124. [CrossRef]

12. Argyris, C. Knowledge for Action: A Guide for Overcoming Barriers to Organizational Change; Jossey-Bass: San Francisco, CA, USA, 1993.

13. Hannah, M.; Freeman, J. Structural Inertia and Organizational Change. Am. Sociol. Rev. 1984, 49, $149-164$. [CrossRef]

14. Vining, A. Internal Market Failure: A Framework for Diagnosing Firm Inefficiency. J. Manag. Stud. 2003, 40, 431-457. [CrossRef]

15. Greenwood, R.; Hinings, C. Understanding Radical Organizational Change: Bringing Together the Old and the New Institutionalism. Acad. Manag. Rev. 1996, 21, 1022-1054.

16. Moynihan, D.; Pandey, S. The Role of Organizations in Fostering Public Service Motivation. Public Adm. Rev. 2007, 67, 40-53. [CrossRef]

17. Fernandez, S.; Choi, Y.; Perry, J. Exploring the Link between Integrated Leadership and Public Sector Performance. Leadersh. Q. 2010, 21, 308-323. [CrossRef]

18. Bessant, J. Self-Care in Public and Community Sector Workplaces. Int. J. Public Adm. 2016, in press. [CrossRef]

19. Lindblom, C. Still Muddling, Not Yet Through. Public Adm. Rev. 1979, 39, 517-526. [CrossRef]

20. Bendor, J. Incrementalism: Dead Yet Flourishing. Public Adm. Rev. 2015, 75, 194-205. [CrossRef]

21. Argote, L. Organizational Learning: Creating, Retaining and Transferring Knowledge; Kluwer: New York, NY, USA, 1999.

22. Bingham, C.; Eisenhardt, K. Rational Heuristics: The Simple Rules that Strategists Learn from Process Experience. Strateg. Manag. J. 2011, 23, 1437-1464. [CrossRef]

23. Ashworth, R.; Boyne, G.; Delbridge, R. Escape from the Iron Cage? Organizational Change and Isomorphic Pressure in the Public Sector. J. Public Adm. Res. Theory 2009, 19, 165-187. [CrossRef]

24. Villadsen, A.; Hansen, J.; Mols, N. When Do Public Managers Imitate Each Other? Mimetic Decision Making in Contracting Decisions of Danish Municipalities. Public Organ. Rev. 2010, 10, 357-376. [CrossRef]

25. Vining, A.; Weimer, D. Policy Analysis: A Valuable Skill for Public Administrators. In Foundations of Public Administration; Raadschelders, J., Stillman, R., Eds.; Melvin and Leigh: Irvine, CA, USA, 2017; pp. 162-176.

26. Bryson, J.; Ackermann, F.; Edin, C. Putting the Resource-Based View of Strategy and Distinctive Competencies to Work in Public Organizations. Public Adm. Rev. 2007, 67, 702-717. [CrossRef]

27. Vining, A.; Boardman, A. Metachoice in Policy Analysis. J. Comp. Policy Anal. Res. Pract. 2006, 8, 77-87. [CrossRef]

28. Howlett, M. Policy Analytic Capacity: The Supply and Demand for Policy Analysis in Government. Policy Soc. 2015, 34, 173-182. [CrossRef]

29. Shields, P.; Whetsell, T. Public Administration Methodology: A Pragmatic Perspective. In Foundations of Public Administration; Raadschelders, J., Stillman, R., Eds.; Melvin and Leigh: Irvine, CA, USA, 2017; pp. 75-92.

30. Tullock, G. The Welfare Costs of Tariffs, Monopolies and Theft. West. Econ. J. 1967, 5, 224-232. [CrossRef]

31. Zupan, M. Rent-Seeking on the Supply Side of Politics. CESifo DICE Rep. 2015, 3, 6-14.

32. Boardman, A.; Greenberg, D.; Vining, A.; Weimer, D. Cost-Benefit Analysis: Concepts and Practice; Pearson Prentice-Hall: Upper Saddle River, NJ, USA, 2011. 
33. Gayer, T.; Viscusi, W.K. Determining The Proper Scope of Climate Change Benefits in U.S. Regulatory Analyses: Domestic versus Global Approaches. Rev. Environ. Econ. Policy 2016, 10, 245-263. [CrossRef]

34. Boardman, A.; Vining, A.; Waters, W. Costs and Benefits through Bureaucratic Lenses: Example of a Highway Project. J. Policy Anal. Manag. 1993, 12, 532-555. [CrossRef]

35. Swan, P.; Belzer, M. Tolling and Economic Efficiency: Do the Pecuniary Benefits Exceed the Safety Costs. Public Works Manag. Policy 2012, 18, 167-184. [CrossRef]

36. Boardman, A.; Vining, A. There Are Many (Well More than One) Paths to Nirvana: The Economic Evaluation of Social Policies. In Handbook of Social Policy Evaluation; Greve, C., Ed.; Edward Elgar: Cheltenham, UK, 2017.

37. Whittington, D.; MacRae, D. The Issue of Standing in Cost-Benefit Analysis. J. Policy Anal. Manag. 1986, 5, 665-682. [CrossRef]

38. Trumbull, W. Who Has Standing in Cost-Benefit Analysis? J. Policy Anal. Manag. 1990, 9, 201-218. [CrossRef]

39. Bosse, J.; Heichlinger, A.; Padovani, E.; Vanebo, J.O. In Search of Local Public Management Excellence: Seven Journeys to Success; European Institute of Public Management: Maastricht, The Netherlands, 2013.

40. Haeder, S.; Weimer, D.; Mukamel, D. Top-Down and Bottom-Up Approaches to Health Care Quality: The Impacts of Regulation and Report Cards. Annu. Rev. Public Health 2014, 35, 477-497.

41. Greco, M.; Cricelli, L.; Grimaldi, M. A Strategic Management Framework of Tangible and Intangible Assets. Eur. Manag. J. 2013, 31, 55-66. [CrossRef]

42. Boisot, M. Information Space: A Framework for Learning in Organizations, Institutions and Culture; Routledge: Oxford, UK, 2013.

43. Boardman, A.; Shapiro, D.; Vining, A. A Framework for Comprehensive Strategic Analysis. J. Strateg. Manag. Educ. 2004, 1, 307-342.

44. Vining, A.R. Public agency external analysis using a modified "five forces" framework. Int. Public Manag. J. 2011, 14, 63-105. [CrossRef]

45. Kelman, S.; Thompson, F.; Jones, L.R.; Schedler, K. Dialogue on Definition and Evolution in the Field of Public Management. Int. Public Manag. J. 2003, 4, 1-19.

46. Kendrick, R. Strategic Planning Environment, Process, and Performance in Public Agencies: A Comparative Study of Departments in Milwaukee. J. Public Adm. Res. Theory 2003, 13, 491-519. [CrossRef]

47. Stewart, J. The Meaning of Strategy in the Public Sector. Aust. J. Public Adm. 2004, 63, 16-21. [CrossRef]

48. Irwin, D. Strategy Mapping in the Public Sector. Long Range Plan. 2002, 35, 637-647. [CrossRef]

49. Selznick, P. Leadership in Administration: A Sociological Interpretation; Harper \& Row: New York, NY, USA, 1957.

50. Bryer, T.A. Toward a relevant agenda for a responsive public administration. J. Public Adm. Res. Theory 2007, 17, 479-500. [CrossRef]

51. Chun, Y.H.; Rainey, H.G. Goal ambiguity and organizational performance in US federal agencies. J. Public Adm. Res. Theory 2005, 15, 1-30. [CrossRef]

52. Pandey, S.K.; Wright, B.E. Connecting the dots in public management: Political environment, organizational goal ambiguity, and the public manager's role ambiguity. J. Public Adm. Res. Theory 2006, 16, 511-532. [CrossRef]

53. Steinberg, R. The revealed objective function of nonprofit firms. RAND J. Econ. 1986, 17, 508-526. [CrossRef]

54. Thompson, F.; Rizova, P. Understanding and creating public value: Business is the engine, government the flywheel (and also the regulator). Public Manag. Rev. 2015, 17, 565-586. [CrossRef]

55. Moore, M.H. Creating Public Value: Strategic Management in Government; Harvard University Press: Cambridge, MA, USA, 1995.

56. Alford, J.; O’Flynn, J. Making Sense of Public Value: Concepts, Critiques and Emergent Meanings. Int. J. Public Adm. 2009, 32, 171-191. [CrossRef]

57. Colebatch, H.K. Valuing public value: Recognizing and applying knowledge about the government process. Aust. J. Public Adm. 2010, 69, 66-78. [CrossRef]

58. Llewellyn, S.; Tappin, E. Strategy in the public sector: Management in the wilderness. J. Manag. Stud. 2003, 40, 955-982. [CrossRef]

59. Nabatchi, T. Putting the "public" back in public value research: Designing participation to identify and respond to values. Public Adm. Rev. 2012, 72, 699-708. [CrossRef]

60. Smith, R.F.I.; Anderson, E.; Teicher, J. Toward public value? Aust. J. Public Adm. 2004, 63, 14-15. [CrossRef]

61. Spano, A. Public value creation and management control systems. Int. J. Public Adm. 2009, 32, 328-348. [CrossRef] 
62. Greve, C. Ideas in Public Management Reform for the 2010s. Digitalization, Value Creation and Involvement. Public Organ. Rev. 2015, 15, 49-65. [CrossRef]

63. Bruijn, H.D.; Dicke, W. Strategies for safeguarding public values in liberalized utility sectors. Public Adm. 2006, 84, 717-735. [CrossRef]

64. O'Flynn, J. From new public management to public value: Paradigmatic change and managerial implications. Aust. J. Public Adm. 2007, 66, 353-366. [CrossRef]

65. Davis, P.; West, K. What do public values mean for public action? Am. Rev. Public Adm. 2009, 39, $602-618$. [CrossRef]

66. Meynhardt, T. Public value inside: What is public value creation? Int. J. Public Adm. 2009, 32, $192-219$. [CrossRef]

67. West, K.; Davis, P. What is the public value of government action?: Towards a (new) pragmatic approach to value questions in public endeavours. Public Adm. 2011, 89, 226-241. [CrossRef]

68. Hartley, J.; Alford, J.; Hughes, O.; Yates, S. Public Value and Political Astuteness in the Work of Public Managers: The Art of the Possible. Public Adm. 2015, 93, 195-211. [CrossRef]

69. Moore, R. The revival of creationism in the United States. J. Bio. Educ. 2000, 35, 17-21. [CrossRef]

70. Andersen, L.B.; Jorgensen, B.T.; Kjeldsen, A.; Pedersen, L.; Vrangbaek, K. Public Value Dimensions: Developing and Testing a Multi-Dimensional Classification. Int. J. Public Adm. 2012, 35, 715-728. [CrossRef]

71. Vining, A.R.; Weimer, D.L. Welfare economics as the foundation for public policy analysis: Incomplete and flawed but nevertheless desirable. J. Socio-Econ. 1992, 21, 25-37. [CrossRef]

72. Vining, A.; Weimer, D.L. An assessment of important issues concerning the application of benefit-cost analysis to social policy. J. Benefit-Cost Anal. 2010, 1, 1-40. [CrossRef]

73. Vining, A.R.; Weimer, D.L. Efficiency and cost-benefit analysis. In Handbook of Public Policy; Peters, B.G., Pierre, J., Eds.; Sage: Thousand Oaks, CA, USA, 2006; pp. 417-432.

74. Vining, A.R.; Weimer, D.L. Policy analysis in representative government. In Promoting the General Welfare: American Democracy and the Political Economy of Government Performance; Gerber, A., Patashnik, A., Eds.; Brookings Institution Press: Washington, DC, USA, 2006; pp. 19-39.

75. Weimer, D.; Vining, A. Policy Analysis: Concepts and Practice, 6th ed.; Longman: Boston, MA, USA, 2011.

76. Mansell, S.F. Capitalism, Corporations and the Social Contract: A Critique of Stakeholder Theory; Cambridge University Press: Cambridge, UK, 2013.

77. Dewey, J. The Public and Its Problems; Holt and Co.: New York, NY, USA, 1927.

78. Wilson, J.Q. Political Organizations; Princeton University Press: Princeton, NJ, USA, 1995.

79. Cuganesan, S.; Lacey, D.M. Developments in Public Sector Performance Measurement: A Project Based on Producing Investment Metrics for Law Enforcement. Financ. Account. Manag. 2011, 27, 458-479. [CrossRef]

80. Sweetman, A.; Frenette, M.; Meyers, K.; Voyer, J.-P. Practical Guide to Understanding Returns to Training Investments; Social Research and Demonstration Corporation: Ottawa, ON, Canada, 2014.

81. Warner, A. Cost-Benefit Analysis in World Bank Projects; The International Bank for Reconstruction and Development/The World Bank: Washington, DC, USA, 2010.

82. Aubuchon, C. From What Perspective? Distributional Accounting within Cost-Benefit Analysis. J. Am. Water Works Assoc. 2013, 105, 619-627. [CrossRef]

83. Zmud, J.; Arce, C. Compilation of Public Opinion Data on Tolls and Road Pricing: A Synthesis of Highway Practice; Transportation Research Board: Washington, DC, USA, 2008.

84. Rouhini, O.; Neimeier, D. Flat versus spatially variable tolling: A case study in Fresno, California. J. Trans. Geogr. 2014, 37, 10-18. [CrossRef]

85. Hall, T.E.; O'Toole, L.J. Structures for Policy Implementation an Analysis of National Legislation, 1965-1966 and 1993-1994. Adm. Soc. 2000, 31, 667-686. [CrossRef]

86. Boyne, G.A. Public Service Performance: Perspectives on Measurement and Management; Cambridge University Press: Cambridge, UK, 2006.

87. Boyne, G.A.; Chen, A.A. Performance targets and public service improvement. J. Public Adm. Res. Theory 2007, 17, 455-477. [CrossRef]

88. Rodgers, R.; Hunter, J.E. A foundation of good management practice in government: Management by objectives. Public Adm. Rev. 1992, 52, 27-39. [CrossRef]

89. Porter, M.E. How Competitive Forces Shape Strategy. Harv. Bus. Rev. 1979, 57, 137-145.

90. Porter, M.E. The Five Competitive Forces that Shape Strategy. Harv. Bus. Rev. 2008, 86, 78-97. [PubMed] 
91. Grant, R. Why Strategy Teaching Should Be Theory Based. J. Manag. Inquiry 2008, 17, 276-281. [CrossRef]

92. Hill, T.; Westbrook, R. SWOT Analysis: It's Time for a Product Recall. Long Range Plan. 1997, 30, 46-52. [CrossRef]

93. Flynn, N.; Talbot, C. Strategy and strategists in UK local government. J. Manag. Dev. 1996, 15, $24-37$. [CrossRef]

94. Hodgkinson, G.P.; Johnson, G.; Whittington, R.; Schwarz, M. The Role and Importance of Strategy Workshops: Findings of a UK Survey; Advanced Institute of Management Research and Chartered Management Institute: London, UK, 2005.

95. Hartley, K.; White, R.; Chaundy, D. Government and industry performance: A comparative study. Appl. Econ. 1997, 29, 1227-1237. [CrossRef]

96. Duggan, M.; Morton, F. The Distortionary Effect of Government Procurement: Evidence from Medicaid Prescription Drug Purchasing. Q. J. Econ. 2006, 121, 1-30. [CrossRef]

97. Swanson, A.; Grennan, M. Transparency and Negotiated Prices: The Value of Information in Hospital-Suppler Bargaining; The Wharton School Research Paper No. 88; The Wharton School: Philadelphia, PA, USA, 2016.

98. Cox, A. Managing with power: Strategies for improving value appropriation from supply relationships. J. Supply Chain Manag. 2001, 37, 42-47. [CrossRef]

99. Cox, A. Understanding buyer and supplier power: A framework for procurement and supply competence. J. Supply Chain Manag. 2001, 37, 8-15. [CrossRef]

100. Crook, T.R.; Combs, J.G. Sources and consequences of bargaining power in supply chains. J. Oper. Manag. 2007, 25, 546-555. [CrossRef]

101. Long, N.E. Power and administration. Public Adm. Rev. 1949, 9, 257-264. [CrossRef]

102. Rourke, F.E. Bureaucracy, Politics and Public Policy; Little Brown: Boston, MA, USA, 1984.

103. Grennan, M. Price Discrimination and Bargaining: Empirical Evidence from Medical Devices. Am. Econ. Rev. 2013, 103, 145-177. [CrossRef]

104. Henderson, R.M.; Clark, K.B. Architectural innovation: The reconfiguration of existing product technologies and the failure of established firms. Adm. Sci. Q. 1990, 35, 9-30. [CrossRef]

105. Christensen, C.M. The Innovator's Dilemma: When New Technologies Cause Great Firms to Fail; Harvard Business School Press: Boston, MA, USA, 1997.

106. Christensen, C.M. The ongoing process of building a theory of disruption. J. Product Innov. Manag. 2006, 23, 39-55. [CrossRef]

107. Bertot, J.C. Public access technologies in public libraries: Effects and implications. Inf. Technol. Libr. 2009, 28, 81-92. [CrossRef]

108. Dalbello, M. A phenomenological study of an emergent national digital library, part I: Theory and methodological framework. Libr. Q. 2005, 75, 391-420. [CrossRef]

109. D'Elia, G.; Jörgensen, C.; Woelfel, J.; Rodger, E.J. The impact of the Internet on public library use: An analysis of the current consumer market for library and Internet services. J. Amer. Soc. Inf. Sci. Technol. 2002, 53, 802-820. [CrossRef]

110. Alford, J. Defining the Client in the Public Sector: A Social Exchange Perspective. Public Adm. Rev. 2002, 62, 337-346. [CrossRef]

111. Wagenheim, G.D.; Reurink, J.H. Customer service in public administration. Public Adm. Rev. 1991, 51, 263-270. [CrossRef]

112. Oster, S.M. Strategic Management for Nonprofit Organizations; Oxford University Press: New York, NY, USA, 1995.

113. Boardman, A.; Vining, A. Using Service-Customer Matrices in Strategic Analysis of Nonprofits. Nonprofit Manag. Leadersh. 2000, 10, 397-420. [CrossRef]

114. Biladou, N.; Laurin, C.; Vining, A.R. Choice of Organizational Form Makes a Real Difference: The Impact of Corporatization on Government Agencies in Canada. J. Public Adm. Res. Theory 2007, 17, 119-147. [CrossRef]

115. Vining, A.R.; Laurin, C.; Weimer, D. The longer-run performance effects of agencification: Theory and evidence from Québec agencies. J. Public Policy 2015, 35, 193-222. [CrossRef]

116. Bloom, N.; Propper, C.; Seiler, S.; Van Reenen, J. The Impact of Competition on Management Quality: Evidence from Public Hospitals. Rev. Econ. Stud. 2015, 82, 457-489. [CrossRef]

117. McCormack, J.; Propper, C.; Smith, S. Herding Cats? Management and University Performance. Econ. J. 2013, 124, F534-F564. [CrossRef] 
118. Amirkhanyan, A.A.; Kim, H.J.; Lambright, K.T. Does the public sector outperform the nonprofit and for-profit sectors? Evidence from a national panel study on nursing home quality and access. J. Policy Anal. Manag. 2008, 27, 326-353. [CrossRef]

119. Liu, Y.; Weinberg, M.S.; Ortega, L.S.; Painter, J.A.; Maloney, S.A. Overseas screening for tuberculosis in US-bound immigrants and refugees. New Engl. J. Med. 2009, 360, 2406-2415. [CrossRef] [PubMed]

120. Carroll, K.A. Bureau competition and inefficiency: A reevaluation of theory and evidence. J. Econ. Behav. Organ. 1990, 13, 21-40. [CrossRef]

121. Krause, G.A.; Douglas, J.W. Does agency competition improve the quality of policy analysis? Evidence from OMB and CBO fiscal projections. J. Policy Anal. Manag. 2006, 25, 53-74. [CrossRef]

122. Nicholson-Crotty, S. Bureaucratic competition in the policy process. Policy Stud. J. 2005, 33, 341-361. [CrossRef]

123. Baumol, W.; Panzar, J.; Willig, R. Contestable Markets and the Theory of Industry Structure; Harcourt College Publisher: New York, NY, USA, 1982.

124. Vining, A.R.; Weimer, D.L. Government supply and government production failure: A framework based on contestability. J. Public Policy 1990, 10, 1-22. [CrossRef]

125. Ting, M.M. A strategic theory of bureaucratic redundancy. Am. J. Political Sci. 2003, 47, 274-292. [CrossRef]

126. Grace, C.; Fletcher, K.; Martin, S.; Bottril, I. Making and Managing Markets: Contestability, Competition and Improvement in Local Government; Audit Commission: London, UK, 2007.

127. Tiebot, C.M. A pure theory of local expenditures. J. Political Econ. 1956, 64, 416-424. [CrossRef]

128. Banzhaf, S.H.; Walsh, R.P. Do people vote with their feet? An empirical test of Tiebout's mechanism. Am. Econ. Rev. 2008, 98, 843-863. [CrossRef]

129. Reenock, C.C.; Gerber, B.J. Political insulation, information exchange, and interest group access to the bureaucracy. J. Public Adm. Res. Theory 2008, 18, 415-440. [CrossRef]

130. Wood, B.D.; Bohte, J. Political transaction costs and the politics of administrative design. J. Politics 2004, 66, 176-202. [CrossRef]

131. Chrisingen, J.; Armajani, B. Beyond bureaucracy with charter agencies. Spectr. J. State Gov. 2005, 78, 35-40.

132. Boster, R.S. The Public Company Accounting Oversight Board: Déjà Vu Seidman's Quasi Government. Public Budg. Financ. 2007, 27, 130-137. [CrossRef]

133. Thatcher, M. Delegation to independent regulatory agencies: Pressures, functions and contextual mediation. West Euro. Politics 2002, 25, 125-147. [CrossRef]

134. Kelleher, C.A.; Yackee, S.W. Who's whispering in your ear? The influence of third parties over state agency decisions. Political Res. Q. 2006, 59, 629-643. [CrossRef]

135. Woods, N.D.; Baranowski, M. Governors and the bureaucracy: Executive resources as sources of administrative influence. Int. J. Public Adm. 2007, 30, 1219-1230. [CrossRef]

136. Hedge, D.M.; Scicchitano, M.J.; Metz, P. The principal-agent model and regulatory federalism. West. Political Q. 1991, 44, 1055-1080.

137. Scholz, J.T.; Twombly, J.; Headrick, B. Street-Level Political Controls over Federal Bureaucracy. Am. Political Sci. Rev. 1991, 85, 829-850. [CrossRef]

138. Wood, B.D. Modeling federal implementation as a system. Am. J. Political Sci. 1992, 36, 40-67. [CrossRef]

139. Wernerfelt, B. A resource-based view of the firm. Strateg. Manag. J. 1984, 5, 171-180. [CrossRef]

140. Barney, J. Firm Resources and Sustained Competitive Advantage. J. Manag. 1991, 17, 99-120. [CrossRef]

141. Grant, R. The Resource-Based Theory of Competitive Advantage: Implications for Strategy Formulation. Calif. Manag. Rev. 1991, 33, 114-135. [CrossRef]

142. Duncan, W.J.; Ginter, P.M.; Swayne, L.E. Competitive advantage and internal organizational assessment. Acad. Manag. Exec. 1998, 12, 6-16. [CrossRef]

143. Matthews, J.; Shulman, A.D. Competitive advantage in public-sector organizations: Explaining the public good/sustainable competitive advantage paradox. J. Bus. Res. 2005, 58, 232-240. [CrossRef]

144. Bryson, J.M.; Roering, W.D. Applying private-sector strategic planning in the public sector. J. Am. Plan. Assoc. 1987, 53, 9-22. [CrossRef]

145. Bovaird, T. Public governance: Balancing stakeholder power in a network society. Int. Rev. Adm. Sci. 2005, 71, 217-228. [CrossRef]

146. Pablo, A.; Reay, T.; Dewald, J.R.; Casebeer, A.L. Identifying, enabling, and managing dynamic capabilities in the public sector. J. Manag. Stud. 2007, 44, 687-708. [CrossRef] 
147. Knutson, H.; Mattison, O.; Ramberg, U.; Tagesson, T. Do Strategy and Management Matter in Municipal Organizations? Financ. Account. Manag. 2008, 24, 295-319. [CrossRef]

148. Johanson, J.-E. Strategy Formation in Public Agencies. Public Adm. 2009, 87, 872-891. [CrossRef]

149. Penrose, E.T. The Theory of the Growth of the Firm; John Wiley: New York, NY, USA, 1959.

150. Hill, D.L.; Deeds, C.W.L. Strategic alliances and the rate of new product development: An empirical study of entrepreneurial biotechnology firms. J. Bus. Ventur. 1996, 11, 41-55.

151. Nelson, R.R.; Winter, S.G. The Schumpeterian tradeoff revisited. Am. Econ. Rev. 1982, 72, 114-132.

152. Dierickx, I.; Cool, K. Asset stock accumulation and sustainability of competitive advantage. Manag. Sci. 1989, 35, 1504-1511. [CrossRef]

153. Thompson, J.D. Organizations in Action: Social Science Bases of Administrative Theory; Transaction Publishers: New Brunswick, NJ, USA, 1967.

154. Porter, M.E. Competitive Advantage; Free Press: New York, NY, USA, 1985.

155. Porter, M.E. The Competitive Advantage of Nations; Free Press: New York, NY, USA, 1990.

156. Stabell, C.; Fjeldstad, O. Configuring Value for Competitive Advantage: On Chains, Shops, and Networks. Strateg. Manag. J. 1998, 19, 413-437. [CrossRef]

157. Rethemeyer, R.K.; Hatmaker, D.M. Mobile Trust, Enacted Relationships: Social Capital in A State-Level Policy Network. AMJ 2007. [CrossRef]

158. Braun, C. The captive or the broker? Explaining public agency-interest group interactions. Governance 2012, 25, 291-314.

159. Klerkx, L.; Leeuwis, C. Matching demand and supply in the agricultural knowledge infrastructure: Experiences with innovation intermediaries. Food Policy 2008, 33, 260-276. [CrossRef]

160. Autor, D.H. Studies in labor market intermediation: Introduction. In Studies in Labor Market Intermediation; Autor, D.H., Ed.; University of Chicago Press: Chicago, IL, USA, 2009.

161. Rosen, L.; Vining, A.; Weimer, D. Addressing the Shortage of Kidneys for Transplantation: Purchase and Allocation through Chain Auctions. J. Health Politics Policy Law 2011, 36, 717-755. [CrossRef] [PubMed]

162. Cole, S.A.; Fernando, A.N. Mobile'izing Agricultural Advice: Technology Adoption, Diffusion, and Sustainability, Harvard Business School Finance Working Paper No. 13-047. 29 April 2016. Available online: https:/ / ssrn.com/abstract=2179008 (accessed on 3 December 2016).

163. Bugge, M.; Bloch, C. Between Bricolage and Breakthroughs-Framing the Many Faces of Public Sector Innovation. Public Money Manag. 2015, 36, 281-288. [CrossRef]

164. Jansson, D.; Smith, S. Design Fixation. Des. Stud. 1991, 12, 3-11. [CrossRef]

165. Arundel, A.; Casali, L.; Hollanders, H. How European Public Sector Agencies Innovate: The Use of Bottom-Up, Policy-Dependent and Knowledge-Scanning Innovation Methods. Res. Policy 2015, 44, 1271-1282. [CrossRef]

166. Whetsell, T.A. The Heroes Program: Child Support Enforcement among Veterans of War. 2011. Available online: https: / / digital.library.txstate.edu/bitstream/handle/10877/3747/WhetsellTravis.pdf?sequence=3 (accessed on 3 December 2016).

167. Hammer, M.; Champy, J. Reengineering the Corporation: A Manifesto for Business Revolution; Harper Collins: New York, NY, USA, 1993.

168. Caudle, S. Managing Information Resources in State Government. Public Adm. Rev. 1990, 50, 515-524. [CrossRef]

169. Thong, J.; Yap, C.-S.; Seah, K.-L. Business Process Reengineering in the Public Sector: The Case of the Housing Development Board in Singapore. J. Manag. Inform. Syst. 2000, 17, 245-270.

170. Kassahun, A. The Effects of Business Process Reengineering on Public Organization Performance (A Developing Economy Context). Ph.D. Thesis, RMIT University, Melbourne, Australia, 2012.

171. Fragoso, J.T. Business Process Reengineering in Government Agencies: Lessons from an Experience in Mexico. J. Serv. Sci. Manag. 2015, 8, 382-392. [CrossRef]

172. Beecher, M.D. Birdsong learning in the laboratory and field. In Ecology and Evolution of Acoustic Communication in Birds; Comstock Publishing Inc.: Sacramento, CA, USA, 1996; pp. 61-78.

173. Costanza, R.; Hart, M.; Posner, S.; Talberth, J. Beyond GDP: The Need for New Measures of Progress; Boston University Creative Services: Boston, MA, USA, 2009.

174. Weimer, D.; Vining, A. Investing in the Disadvantaged: Assessing the Benefits and Costs of Social Programs; Georgetown University Press: Washington, DC, USA, 2009. 
175. New York State, Department of Public Service (NYDPS). Staff White Paper on Benefit-Cost Analysis in the Reforming Energy Vision Proceeding; 14-M-101; NYDPS: Albany, NY, USA, 2015.

176. Arrow, K.; Cropper, M.L.; Eads, G.C.; Hahn, R.W.; Lave, L.B.; Noll, R.G.; Portney, P.R.; Russell, M.; Smith, V.K.; Stavins, R.N.; et al. Is there a role for benefit-cost analysis in environmental, health, and safety regulation? Science 1995, 272, 221-222. [CrossRef]

177. Nijkamp, P.P. Theory and Application of Environmental Economics; North-Holland: Amsterdam, The Netherlands, 1997.

178. Reyes, J.W. Lead exposure and behavior: Effects on antisocial and risky behavior among children and adolescents. Econ. Inq. 2015, 53, 1580-1605. [CrossRef]

179. Vining, A.; Meredith, L. Metachoice for Strategic Analysis. Eur. Manag. J. 2000, 18, 605-618. [CrossRef]

180. Laise, D.; Marraro, L.; Iazzolino, G. Metachoice for Benchmarking: A Case Study. Benchmark. Int. J. 2015, 22, 338-353. [CrossRef]

181. Hansen, J.R.; Ferlie, E. Applying Strategic Management Theories in Public Sector Organizations. Public Manag. Rev. 2016, 18, 1-19. [CrossRef]

182. Potoski, M. Managing Uncertainty through Bureaucratic Design: Administrative Procedures and State Air Pollution Control Agencies. J. Public Adm. Res. Theory 1999, 9, 623-639. [CrossRef]

183. Abelson, D. Any Ideas? Think Tanks and Policy Analysis in Canada. In Policy Analysis in Canada: The State of the Art; Dobuzinski, L., Howlett, M., Laycock, D., Eds.; University of Toronto Press: Toronto, Canada, 2007; pp. 551-573.

184. Aucoin, P. Accountability and Coordination with Independent Foundations: A Canadian Case of Autonomization. In Autonomy and Regulation: Coping with Agencies in the Modern State; Christensen, T., Laegreid, P., Eds.; Edward Elgar: Cheltenham, UK, 2006; pp. 110-136.

185. Weimer, D.L. Medical Governance: Values, Expertise, and Interests in Organ Transplantation; Georgetown University Press: Washington, DC, USA, 2010.

186. Khademian, A. Bankruptcies, Bailouts and the Banking Bureaucracy: The Bush Agenda and the Capacity for Crisis. Forum 2009, 7, 5. Available online: http://www.bepress.com/forum/vol7/iss4/art5 (accessed on 3 December 2016). [CrossRef]

187. Horwitz, S. Making Hurricane Response More Effective: Lessons from the Private Sector and the Coast Guard during Katrina; Mercatus Policy Comment, No. 17; Mercatus Center: Arlington, VA, USA, 2008.

188. Kennedy, P.; Perrottet, C.; Thomas, C. Scenario Planning after 9/11: Managing the Impact of Catastrophic Events. Strategy Leadersh. 2003, 31, 4-13. [CrossRef]

189. Corrêa d'Almeida, A.; Klingner, D.E. FEMA and the Witt Revolution: Testing the Hypothesis of 'Bureaucratic Autonomy'. Public Organ. Rev. 2008, 8, 291-305.

190. Wise, C.R. Organizing for Homeland Security after Katrina: Is adaptive management what's missing? Public Adm. Rev. 2006, 66, 302-318. [CrossRef]

191. Globerman, S.; Vining, A.R. A framework for evaluating the government contracting-out decision with an application to information technology. Public Adm. Rev. 1996, 56, 577-586. [CrossRef]

192. Frantz, R. X-efficiency and allocative efficiency: What have we learned? Am. Econ. Rev. 1992, 82, 434-438.

193. Prendergast, C. A Theory of Yes Men. Am. Econ. Rev. 1993, 83, 757-770.

194. Garicano, L.; Posner, R.A. Intelligence failures: An organizational economics perspective. J. Econ. Perspect. 2005, 19, 151-170. [CrossRef]

195. Walsh, E.; Eilperin, J. FEC's Structure is 'Ineffectual,' Critics Say; The Washington Post: Washington, DC, USA, 2002; Volume A2.

196. Psaty, B.M.; Burke, S.P. Protecting the health of the public-Institute of Medicine recommendations on drug safety. New Eng. J. Med. 2006, 355, 1753-1755. [CrossRef] [PubMed]

197. Card, M.; Card, K.A. Public Sector Competitive Strategies: Understanding Post Secondary Distance Education in South Dakota. Int. J. Public Adm. 2007, 30, 461-481. [CrossRef]

198. Vining, A.R.; Weimer, D.L. Economic perspectives on public organizations. In The Oxford Handbook of Public Management; Ferlie, E., Lynn, L.E., Pollitt, C., Eds.; Oxford University Press: Oxford, UK, 2005; pp. $209-233$.

199. McCubbins, M.D.; Noll, R.G.; Weingast, B.R. Administrative procedures as instruments of political control. J. Law Econ. Organ. 1987, 3, 243-277.

200. McCubbins, M.D.; Noll, R.G.; Weingast, B.R. Structure and process, politics and policy: Administrative arrangements and the political control of agencies. Va. Law Rev. 1989, 75, 431-482. [CrossRef] 
201. Norton, B. Bell Boeing V-22 Osprey, Tiltrotor Tactical Transport; Midland Publishing Ltd.: Hinckley, UK, 2004.

202. Abels, R. Paying the Danegeld: Anglo-Saxon Peacemaking with Vikings. In War and Peace in Ancient and Medieval History; De Souza, P., France, J., Eds.; Cambridge University Press: Cambridge, UK, 2008; pp. 173-192.

203. Geddes, R. Pricing by State-Owned Enterprises: The Case of Postal Services. Manag. Decis. Econ. 2008, 29, 575-591. [CrossRef]

204. Tarschys, D. Time Horizons in Budgeting. OECD J. Budg. 2002, 2, 77-103. [CrossRef]

205. Vining, A.R.; Weimer, D.L. Assessing the Costs and Benefits of Social Policies. In Investing in the Disadvantaged: Assessing the Benefits and Costs of Social Policies; Georgetown University Press: Washington, DC, USA, 2009; p. 1.

(C) 2016 by the author; licensee MDPI, Basel, Switzerland. This article is an open access article distributed under the terms and conditions of the Creative Commons Attribution (CC-BY) license (http:/ / creativecommons.org/licenses/by/4.0/). 